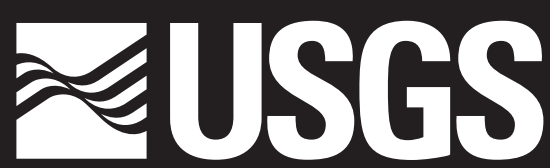

science for a changing world

Prepared in cooperation with the

Massachusetts Department of Environmental Protection

\title{
Factors Affecting Firm Yield and the Estimation of Firm Yield for Selected Streamflow-Dominated Drinking-Water-Supply Reservoirs in Massachusetts
}

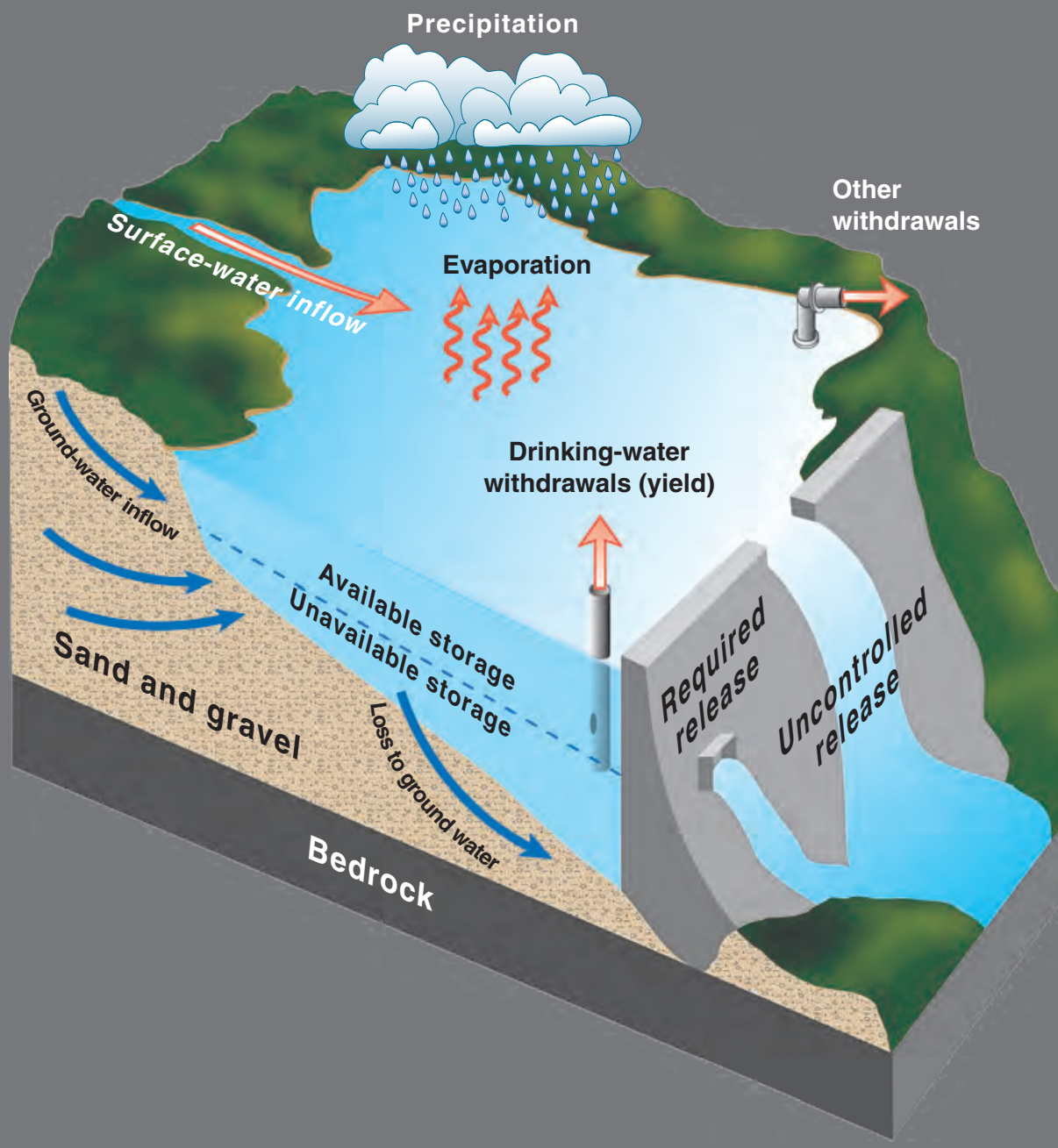

Scientific Investigations Report 2006-5044

U.S. Department of the Interior

U.S. Geological Survey 
Cover: Diagram of possible sources and losses of water to a drinking water reservoir. 


\section{Factors Affecting Firm Yield and the Estimation of Firm Yield for Selected Streamflow-Dominated Drinking-Water- Supply Reservoirs in Massachusetts}

By Marcus C. Waldron and Stacey A. Archfield

Prepared in cooperation with the

Massachusetts Department of Environmental Protection

Scientific Investigations Report 2006-5044

U.S. Department of the Interior

U.S. Geological Survey 


\section{U.S. Department of the Interior \\ Gale A. Norton, Secretary \\ U.S. Geological Survey \\ P. Patrick Leahy, Acting Director}

\section{U.S. Geological Survey, Reston, Virginia: 2006}

For product and ordering information:

World Wide Web: http://www.usgs.gov/pubprod

Telephone: 1-888-ASK-USGS

For more information on the USGS--the Federal source for science about the Earth, its natural and living resources, natural hazards, and the environment:

World Wide Web: http://www.usgs.gov

Telephone: 1-888-ASK-USGS

Any use of trade, product, or firm names is for descriptive purposes only and does not imply endorsement by the U.S. Government.

Although this report is in the public domain, permission must be secured from the individual copyright owners to reproduce any copyrighted materials contained within this report.

Suggested citation:

Waldron, M.C., and Archfield, S.A., 2006, Factors affecting firm yield and the estimation of firm yield for selected streamflow-dominated drinking-water-supply reservoirs in Massachusetts: U.S. Geological Survey Scientific Investigations Report 2006-5044, 39 p. 


\section{Contents}

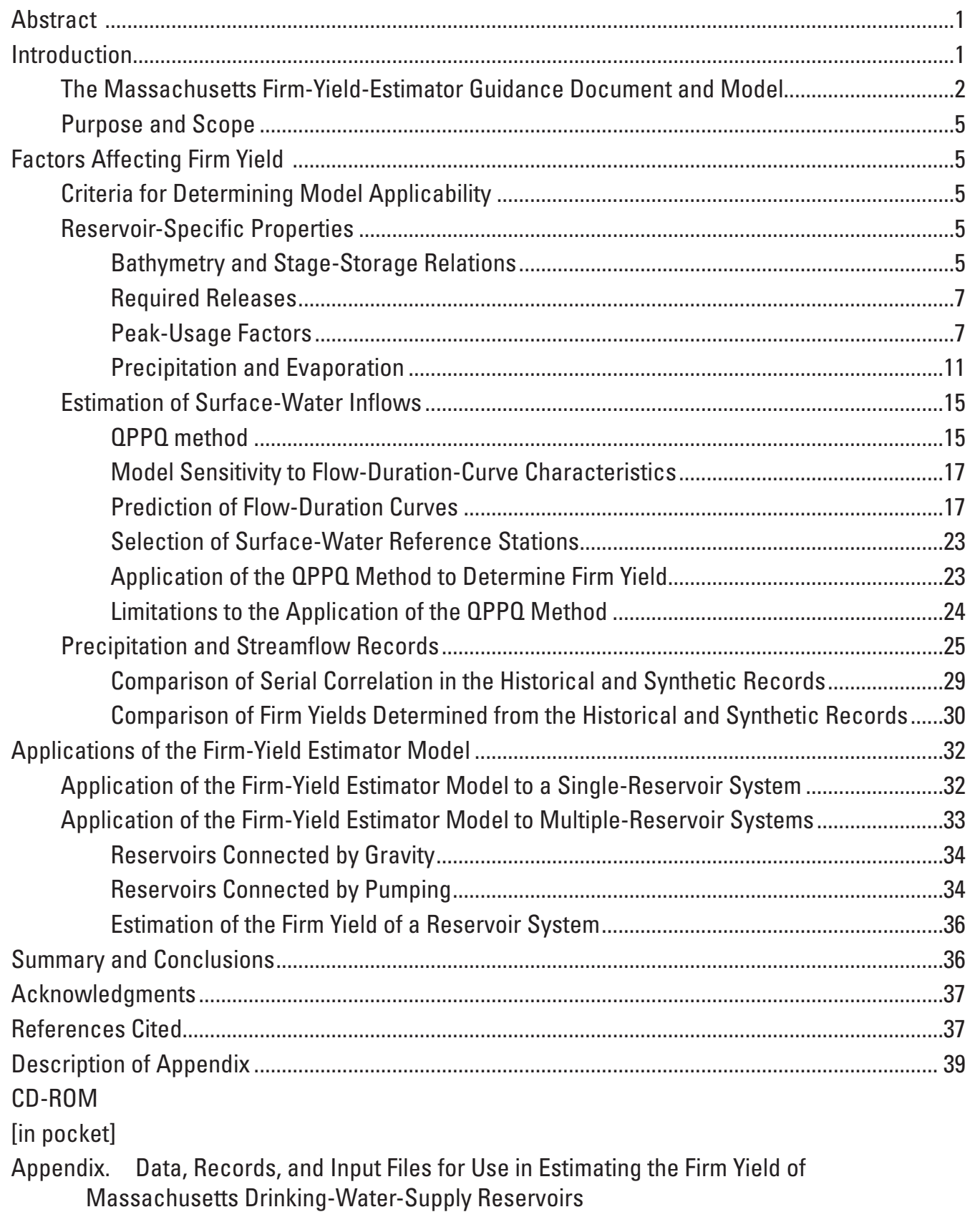




\section{Figures}

1. Diagram showing possible sources and losses of water to a drinking-water reservoir

2. Graph showing changes in Bearhole Reservoir's usable storage that resulted from withdrawing the yield that allowed for no more than one monthly reservoir failure during the historical period of record, West Springfield Water Department, West Springfield, Massachusetts......

3-4. Maps showing:

3. Locations of drainage areas for 46 drinking-water reservoirs

4. Locations of climate stations whose records were used in the Massachusetts Firm-Yield Estimator model and the locations of drainage areas for 46 drinkingwater reservoirs.

5. Diagram showing description of the QPPQ method, which estimates daily streamflow at an ungaged location by equating the exceedence probability of a given flow at the gaged location with the exceedence probability at the ungaged location

6-7. Graphs showing:

6. Sensitivity of streamflow at the 10-, 50-, and 90-percent exceedence probabilities calculated by the QPPO method to values of drainage-area characteristics for four drinking-water reservoirs: $A$, Granville Reservoir, Westfield Water Department; $B$, Belmont Reservoir, Hinsdale Water Department; $C$, Hatchet Pond, Southbridge Water Department; and D, Millham Reservoir, Marlborough DPW-Water and Sewer Division

7. Flow-duration curves for $A$, Sevenmile River near Spencer, Mass. (01175670); and $B$, Old Swamp River near South Weymouth, Mass. (01105600) measured and estimated by applying the QPPO method to records from six streamflowgaging stations in different hydrologic settings.

8. Map showing locations of index streamflow-gaging stations that could be used to estimate streamflow by the QPPO method and the locations of drainage areas for 46 drinking-water reservoirs

9-11. Graphs showing:

9. Comparison of estimated streamflows into Scott Reservoir from October 1949 through September 1951, Fitchburg Water Department.

10. Relationship between the block length used to bootstrap a synthetic record of streamflow and the percentage of serial correlation in the observed streamflow that is preserved in the synthetic record

11. Comparison of firm yields determined from the historical record and 30 synthetic records constructed by bootstrapping 2-year blocks of the historical record for $A$, Bearhole Reservoir, West Springfield Water Department; $B$, Upper (Leahey) Reservoir, Lee Water Department; $C$, Fall Brook Reservoir, Leominster Department of Public Works-Water Division; and D, Cleveland Reservoir, Pittsfield Water Department.

12. Water balances for a system of reservoirs in which $A$, water is released from reservoir 1 in an uncontrolled manner and is transported by gravity to reservoir 2; and $B$, water is pumped from reservoir 1 to reservoir 2 


\section{Tables}

1. Massachusetts drinking-water-supply systems and associated reservoirs used to investigate factors affecting reservoir firm yield

2. Reservoir and drainage-basin characteristics for 70 Massachusetts drinking-water-supply reservoirs.

3. Reservoir-specific properties for 46 drinking-water-supply reservoirs ...........................12

4. Climate, soil, and basin characteristics for 46 drinking-water-supply reservoirs ...........18

5. Locations, drainage-basin characteristics, and climate data for streamflowmonitoring stations whose records were used to compare methods that estimate streamflow at an ungaged site

6. Identifiers, names, drainage areas, and records for 26 streamflow-monitoring stations that could be used to estimate surface-water flows to reservoirs

7. Streamflow-monitoring stations used as reference stations to estimate reservoir inflows, portions of streamflow records estimated for the stations, index stations used in the estimation, and correlation coefficients between log-transformed flow records for index and target stations.

8. Firm-yield estimates determined by the historical record of streamflow and precipitation for 14 single-reservoir systems

9. Firm-yield estimates determined by the historical record of streamflow and precipitation for 31 reservoirs belonging to one of 11 multiple-reservoir systems. 


\section{Conversions Factors and Datums}

\begin{tabular}{|c|c|c|}
\hline Multiply & By & To obtain \\
\hline \multicolumn{3}{|c|}{ Length } \\
\hline inch (in.) & 2.54 & centimeter $(\mathrm{cm})$ \\
\hline inch (in.) & 25.4 & millimeter (mm) \\
\hline foot $(\mathrm{ft})$ & 0.3048 & meter $(\mathrm{m})$ \\
\hline mile (mi) & 1.609 & kilometer $(\mathrm{km})$ \\
\hline \multicolumn{3}{|c|}{ Area } \\
\hline acre & 4,047 & square meter $\left(\mathrm{m}^{2}\right)$ \\
\hline acre & 0.4047 & hectare (ha) \\
\hline square mile $\left(\mathrm{mi}^{2}\right)$ & 259.0 & hectare (ha) \\
\hline square mile $\left(\mathrm{mi}^{2}\right)$ & 2.590 & square kilometer $\left(\mathrm{km}^{2}\right)$ \\
\hline \multicolumn{3}{|c|}{ Volume } \\
\hline gallon (gal) & 3.785 & liter (L) \\
\hline million gallons (Mgal) & 3,785 & cubic meter $\left(\mathrm{m}^{3}\right)$ \\
\hline \multicolumn{3}{|c|}{ Flow rate } \\
\hline cubic foot per second $\left(\mathrm{ft}^{3} / \mathrm{s}\right)$ & 0.02832 & cubic meter per second $\left(\mathrm{m}^{3} / \mathrm{s}\right)$ \\
\hline $\begin{array}{l}\text { cubic foot per second per square } \\
\text { mile }\left[\left(\mathrm{ft}^{3} / \mathrm{s}\right) / \mathrm{mi}^{2}\right]\end{array}$ & 0.01093 & $\begin{array}{l}\text { cubic meter per second per square } \\
\text { kilometer }\left[\left(\mathrm{m}^{3} / \mathrm{s}\right) / \mathrm{km}^{2}\right]\end{array}$ \\
\hline million gallons per day (Mgal/d) & 0.04381 & cubic meter per second $\left(\mathrm{m}^{3} / \mathrm{s}\right)$ \\
\hline \multicolumn{3}{|l|}{ 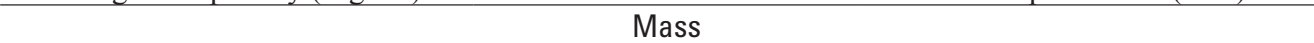 } \\
\hline ounce, avoirdupois (oz) & 28.35 & gram (g) \\
\hline pound, avoirdupois (lb) & 0.4536 & kilogram (kg) \\
\hline ton, short $(2,000 \mathrm{lb})$ & 0.9072 & megagram $(\mathrm{Mg})$ \\
\hline ton, long $(2,240 \mathrm{lb})$ & 1.016 & megagram $(\mathrm{Mg})$ \\
\hline ton per day (ton/d) & 0.9072 & metric ton per day \\
\hline ton per day (ton/d) & 0.9072 & megagram per day $(\mathrm{Mg} / \mathrm{d})$ \\
\hline $\begin{array}{l}\text { ton per day per square mile } \\
{\left[(\text { ton } / \mathrm{d}) / \mathrm{mi}^{2}\right]}\end{array}$ & 0.3503 & $\begin{array}{l}\text { megagram per day per square } \\
\text { kilometer }\left[(\mathrm{Mg} / \mathrm{d}) / \mathrm{km}^{2}\right]\end{array}$ \\
\hline ton per year (ton/yr) & 0.9072 & megagram per year $(\mathrm{Mg} / \mathrm{yr})$ \\
\hline ton per year (ton/yr) & 0.9072 & metric ton per year \\
\hline \multicolumn{3}{|c|}{ Hydraulic gradient } \\
\hline foot per mile (ft/mi) & 0.1894 & meter per kilometer $(\mathrm{m} / \mathrm{km})$ \\
\hline \multicolumn{3}{|c|}{ Temperature in degrees Celsius $\left({ }^{\circ} \mathrm{C}\right)$ may be converted to degrees Fahrenheit $\left({ }^{\circ} \mathrm{F}\right)$ as follows: } \\
\hline \multicolumn{3}{|c|}{${ }^{\circ} \mathrm{F}=\left(1.8 \times{ }^{\circ} \mathrm{C}\right)+32$} \\
\hline \multicolumn{3}{|c|}{ Horizontal coordinate information is referenced to the North American Datum of 1983 (NAD 83). } \\
\hline Vertical coordinate information & ferenced to th & eodetic Vertical Datum of 1929. \\
\hline titude as used in this report & 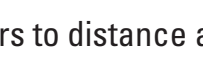 & N NGVD 29. \\
\hline
\end{tabular}




\title{
Factors Affecting Firm Yield and the Estimation of Firm Yield for Selected Streamflow-Dominated Drinking- Water-Supply Reservoirs in Massachusetts
}

\author{
By Marcus C. Waldron and Stacey A. Archfield
}

\begin{abstract}
Factors affecting reservoir firm yield, as determined by application of the Massachusetts Department of Environmental Protection's Firm Yield Estimator (FYE) model, were evaluated, modified, and tested on 46 streamflow-dominated reservoirs representing 15 Massachusetts drinking-water supplies. The model uses a mass-balance approach to determine the maximum average daily withdrawal rate that can be sustained during a period of record that includes the $1960 \mathrm{~s}$ drought-of-record.

The FYE methodology to estimate streamflow to the reservoir at an ungaged site was tested by simulating streamflow at two streamflow-gaging stations in Massachusetts and comparing the simulated streamflow to the observed streamflow. In general, the FYE-simulated flows agreed well with observed flows. There were substantial deviations from the measured values for extreme high and low flows. A sensitivity analysis determined that the model's streamflow estimates are most sensitive to input values for average annual precipitation, reservoir drainage area, and the soil-retention number-a term that describes the amount of precipitation retained by the soil in the basin.

The FYE model currently provides the option of using a 1,000-year synthetic record constructed by randomly sampling 2-year blocks of concurrent streamflow and precipitation records 500 times; however, the synthetic record has the potential to generate records of precipitation and streamflow that do not reflect the worst historical drought in Massachusetts. For reservoirs that do not have periods of drawdown greater than 2 years, the bootstrap does not offer any additional information about the firm yield of a reservoir than the historical record does. For some reservoirs, the use of a synthetic record to determine firm yield resulted in as much as a 30-percent difference between firm-yield values from one simulation to the next. Furthermore, the assumption that the synthetic traces of streamflow are statistically equivalent to the historical record is not valid.
\end{abstract}

For multiple-reservoir systems, the firm-yield estimate was dependent on the reservoir system's configuration. The firm yield of a system is sensitive to how the water is transferred from one reservoir to another, the capacity of the connection between the reservoirs, and how seasonal variations in demand are represented in the FYE model.

Firm yields for 25 (14 single-reservoir systems and 11 multiple-reservoir systems) reservoir systems were determined by using the historical records of streamflow and precipitation. Current water-use data indicate that, on average, 20 of the 25 reservoir systems in the study were operating below their estimated firm yield; during months with peak demands, withdrawals exceeded the firm yield for 8 reservoir systems.

\section{Introduction}

Growing demands on Massachusetts drinking-water supplies have increased the likelihood that withdrawals could deplete available storage capacity and result in supply shortfalls. Although a supplier may be meeting the current demands on the supply system, a severe drought, such as the one that occurred in the 1960s, may not allow the delivery of the reservoir's current yield. Therefore, water suppliers, planners, and regulators must evaluate the reservoir's behavior under drought conditions. A common way to evaluate reservoir behavior is by calculating a firm yield for the reservoir, defined as the maximum yield that can be delivered by the reservoir, even through a severe drought. Ideally, the firm yield would be determined from a period of record that included the worst drought likely to affect the reservoir.

Firm-yield estimates typically are not based on streamflow and precipitation data that include the drought-of-record because these data are unavailable for most drinking-water supply reservoirs. Furthermore, even at monitored locations where streamflow and precipitation data are available, the length of the record often does not include the drought-ofrecord. Because of these limitations, Massachusetts drinking- 
water suppliers have estimated the firm yield of a reservoir by employing regional storage-yield curves developed by the New England Water Works Association (1969). These curves relate maximum available storage to reservoir firm yield per square mile of drainage area on the basis of four watersheds in southern New England. Although this method enables the estimation of the firm yield at sites with little or no data, the curves were developed for only a small number of sites; reservoirs in areas with differing hydrologic characteristics or with different storage features may not have been well represented by the method.

In the past decade, Fennessey (1994) and Fennessey and Vogel (1996) developed techniques to estimate streamflow into and evaporation from a reservoir for which monitoring data are unavailable. On the basis of these developments, the Massachusetts Department of Environmental Protection's (MassDEP) Drinking Water Program developed a Firm-YieldEstimator (FYE) guidance document (MassDEP, 1996) and model (MassDEP, 2000) to estimate the firm yield of a reservoir or system of reservoirs.

MassDEP now requires public water suppliers to use the FYE guidance document to calculate the firm yield of their systems; however, a model developed from the FYE guidance document has not been rigorously tested with respect to its input variables and estimation procedures. Therefore, the U.S. Geological Survey, in cooperation with the MassDEP, determined how the input variables affect estimates of the firm yield, evaluated the procedure to determine firm yield, and, where necessary, modified the procedure to estimate firm yield based on the results of the evaluations.

\section{The Massachusetts Firm-Yield-Estimator Guidance Document and Model}

The MassDEP (1996) guidance document outlines a procedure to estimate the firm yield of a single reservoir or a system of reservoirs. The firm yield is estimated by constructing a monthly water balance for the reservoir and applying techniques developed by Fennessey (1994) and Fennessey and Vogel (1996) to estimate streamflow to and evaporation from a reservoir where direct measurements are not available.

The MassDEP (1996) guidance document defines the firm yield of a single reservoir as the maximum yield that results in the complete depletion of the reservoir's usable storage for no more than one month of a period of record. According to the procedure outlined in the MassDEP (1996) guidance document, a firm yield is first estimated from the historical records of streamflow and precipitation as well as from additional inputs and outputs of water to the reservoir (fig. 1). If a reservoir is connected in a system of reservoirs, these reservoirs receive water from or give water to another reservoir and, therefore, have an additional source or sink of water that must be accounted for in the reservoir's water balance.

The MassDEP (1996) guidance document requires that this preliminary estimate of the firm yield be calculated by using streamflow determined by the area-ratio technique and the water-balance equation

$$
\underbrace{S(i, j)}_{\text {storage }}=\underbrace{Q_{s i}(i, j)}_{\text {inflow }}-\underbrace{\alpha(j) n(j) Q_{y}-Q_{r}(j)-Q_{s o}(i, j)}_{\text {outflow }}+\underbrace{S(i, j-1)}_{\substack{\text { previous } \\ \text { storage }}},
$$

where

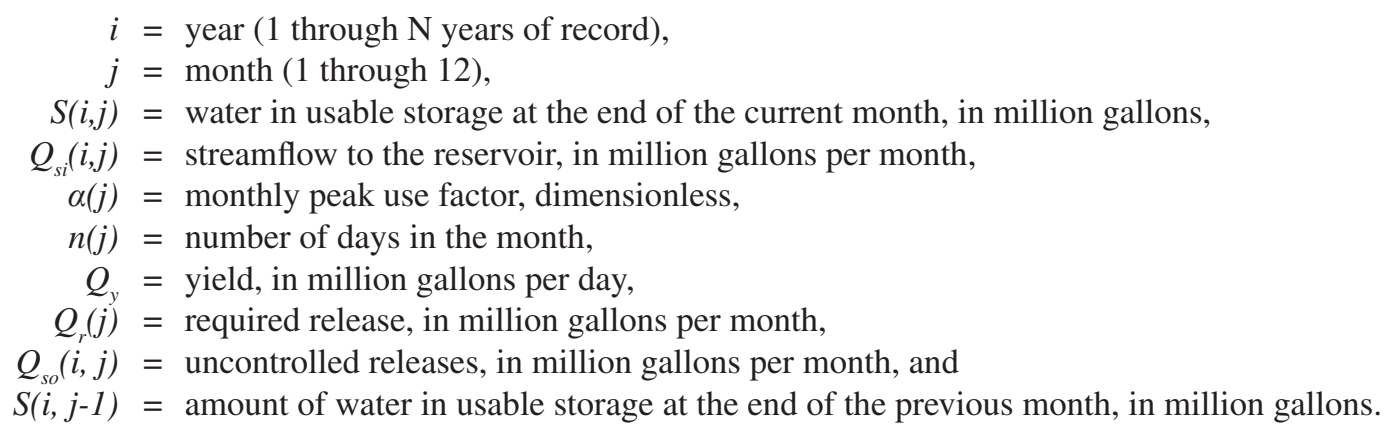

The water-balance equation (equation 1) is solved for each month of the historical record in chronological order. The yield, $Q_{y}$, is initially set equal to zero and is incrementally increased until the reservoir's usable storage is completely depleted during no more than one month of the simulation period. The resulting yield — the final value of $Q_{y}$-is considered the firm yield of the reservoir. The firm yield calculated from the historical record does not include precipitation to or evaporation from the reservoir's surface. 
After the estimate of the firm yield is determined from the historical record, the usable storage for each month is plotted versus time (fig. 2). The number of years the reservoir did not refill is counted and divided by the total number of years in the historical record. If the reservoir does not refill within a year for 15 percent or more of the years, the firm yield is estimated from a 1,000-year synthetic record of streamflow and precipitation. The firm yield is then computed by using the water-balance equation described below (equation 2), which is similar to the water-balance equation for the historical record (equation 1) but includes direct precipitation to and evaporation from the reservoir's surface and streamflow (MassDEP, 1996):

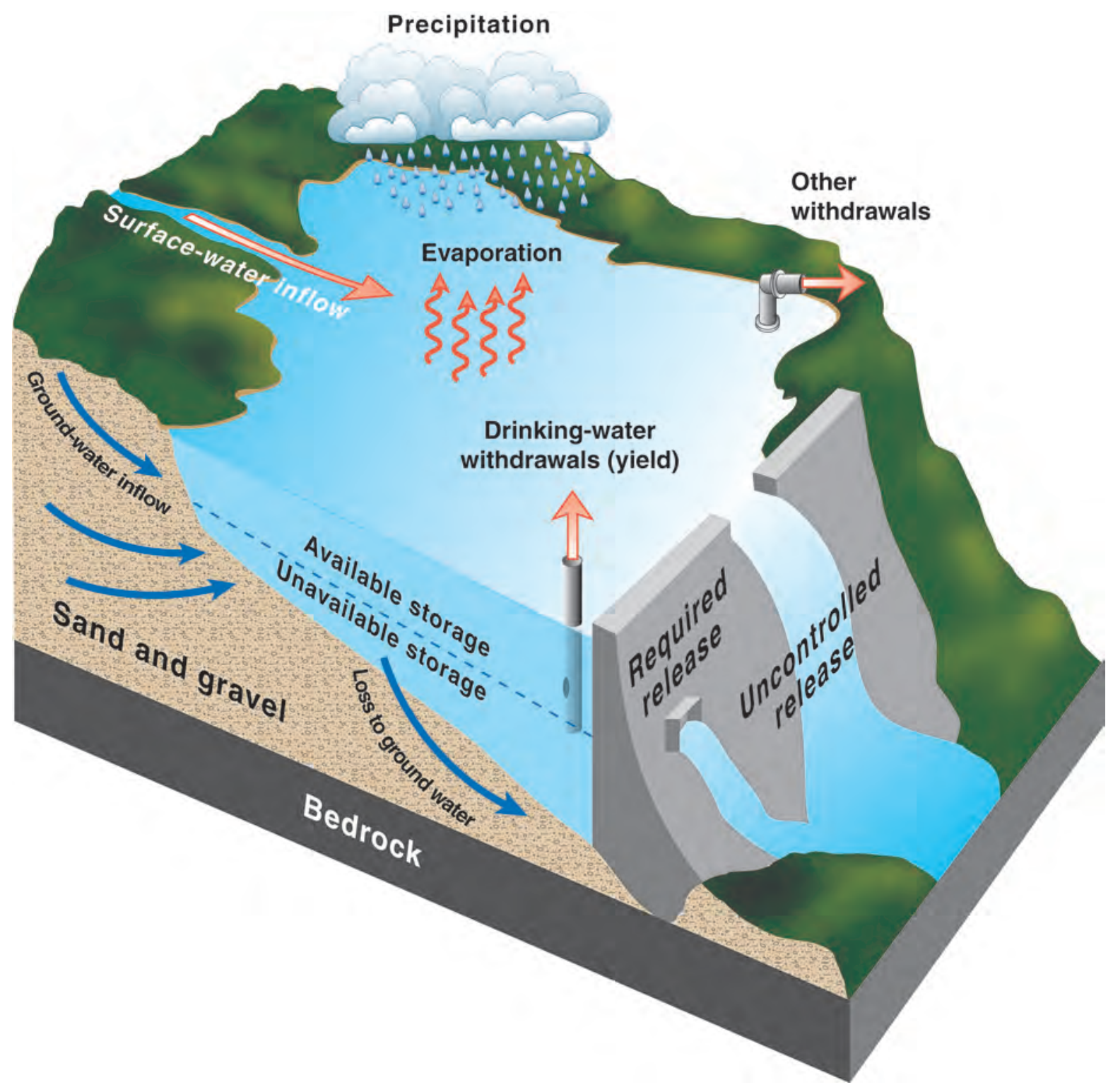

Figure 1. Possible sources and losses of water to a drinking-water reservoir. 
$\underbrace{S(i, j)}_{\text {storage }}=\underbrace{A_{r}(j) P(j)+A_{w} Q_{s i}(i, j)}_{\text {inflow }}-\underbrace{\alpha(j) n(j) Q_{y}-Q_{r}(j)-Q_{s o}(i, j)-Q_{o w}(j)-A_{r}(j) E(j)}_{\text {outflow }}+\underbrace{S(i, j-1),}_{\text {previous stage }}$

where

$i=$ year (1 through $\mathrm{N}$ years of record),

$j=$ month (1 through 12),

$S(i, j)=$ water in usable storage at the end of the current month, in million gallons,

$A_{r}(j)=$ area of the reservoir surface, in miles squared, ${ }^{1}$

$P(j)=$ precipitation, in miles, ${ }^{1}$

$A_{w}(j)=$ contributing drainage area, in miles squared, ${ }^{1}$

$Q_{s i}(i, j)=$ streamflow per square mile of drainage area to the reservoir, in miles, ${ }^{1}$

$\alpha(j)=$ monthly peak use factor, dimensionless,

$n(j)=$ number of days in the month,

$Q_{y}=$ yield, in million gallons per day,

$Q_{r}(j)=$ required release, in million gallons per month,

$Q_{s o}(i, j)=$ uncontrolled release, in million gallons per month,

$Q_{o w}(j)=$ withdrawals from the reservoir by other users, in million gallons per month,

$E(j)=$ evaporation from the reservoir, in miles, ${ }^{1}$ and

$S(i, j-1)=$ amount of water in usable storage at the end of the previous month, in million gallons.

'Precipitation, evaporation, and streamflow are in units of length and, when multiplied by area, become volume terms that are converted to million gallons.

The same sequence of calculations is followed for the water-balance equation for the historical record, but in this case, the sequence of calculations is applied to a 1,000-year synthetic record, which is generated by randomly sampling - 500 times-the historical record for 2-year blocks of concurrent streamflow and precipitation.

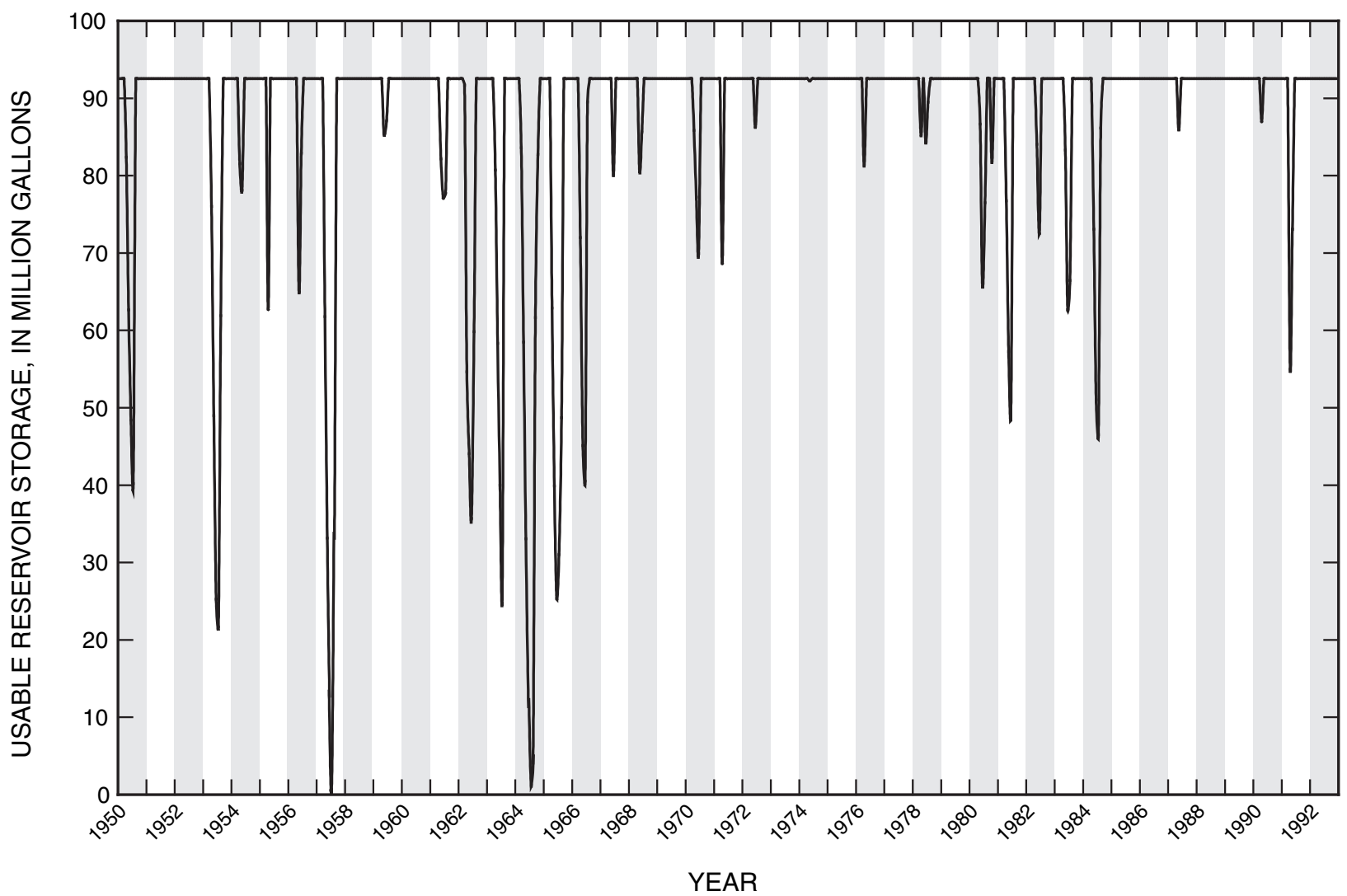

Figure 2. Changes in Bearhole Reservoir's usable storage that resulted from withdrawing the yield that allowed for no more than one monthly reservoir failure during the historical period of record, West Springfield Water Department, West Springfield, Massachusetts. 


\section{Purpose and Scope}

This report examines the factors affecting the MassDEP Drinking Water Program's FYE procedure to determine firm yield, and provides data and criteria for selecting input data sets and compiling other data needed to operate the model successfully. Criteria for determining the applicability of the model were evaluated on the basis of the dominant source of water to the reservoir system (ground or surface water). The report describes these criteria, which were used to select 15 Massachusetts drinking-water-supply systems consisting of single or multiple surface-water reservoirs for detailed investigation. Input data sets were compiled for each of these systems from March 2003 through May 2004. The report also describes the model sensitivities to variations in selected input values, including surface-water-inflow estimates to reservoir systems and modifications to the MassDEP (1996) procedure that resulted from the application of the FYE model to drinking-water reservoirs in Massachusetts. An evaluation of the data needed for the calculation of firm yield and the firm yield of the study reservoir systems are presented in an appendix to the report.

\section{Factors Affecting Firm Yield}

The maximum allowable rate of water withdrawal from a drinking-water-supply reservoir depends on several factors, including reservoir storage, local climatic patterns, the efficiency with which the drainage basin conveys water to the reservoir, and the construction of the record used to calculate the firm yield. If a drinking-water-supply system contains multiple reservoirs, the reservoir-system configuration also affects the firm-yield value. For this analysis, 46 reservoirs and reservoir systems belonging to 15 public water suppliers in Massachusetts were chosen to represent a range of configurations and drainage-basin characteristics (table 1; fig. 3).

\section{Criteria for Determining Model Applicability}

The FYE model, as currently configured, is applicable only to reservoirs that receive most inflows from surface-water sources and have no outflows other than to surface water. Consequently, the first consideration was to develop selection criteria to ensure that the study reservoirs met these requirements. Data on surface area, drainage area, the distribution of sand and gravel in the drainage basin, and the percentage of the reservoir perimeter that is in contact with sand and gravel were compiled for 70 candidate study reservoirs (table 2). It was anticipated that a high percentage of sand and gravel in the drainage basin, a high percentage of sand and gravel along the reservoir perimeter, and a high ratio of reservoir surface area to drainage area would indicate the potential for significant ground-water inflow. There were no demonstrable patterns or trends in the data that could be used to assess the potential for ground-water inflows unambiguously; therefore, an arbitrary set of criteria was applied to the selection of the study reservoirs. In general, the following three criteria were used:

1. The reservoir drainage area was at least four times greater than the reservoir surface area;

2. Sand and gravel occupied no more than 10 percent of the drainage area, exclusive of the reservoir area; and

3. Less than 5 percent of the perimeter of the reservoir was in contact with sand and gravel.

\section{Reservoir-Specific Properties}

Properties specific to reservoirs that influence model estimates of firm yield include the shape and volume of the impoundment, the relation between that volume and the reservoir surface area, the locations of intakes and spillways, the rates of withdrawals by water suppliers and other users, unintentional releases, and intentional releases that may be required to augment downstream flows. Reservoir size and shape, as well as geographical location, also influence the amount of precipitation and evaporation.

\section{Bathymetry and Stage-Storage Relations}

Bathymetric data were unavailable at the outset for most of the 46 reservoirs included in the study. These data are essential for determining available storage capacity and the change in reservoir surface area as storage is depleted. Consequently, bathymetric surveys were done on 37 reservoirs during spring 2002, when the reservoirs were full or nearly full. Bathymetric data consisted of positions, determined to within about $3 \mathrm{ft}$ with a global positioning system (GPS), and depths, determined to within about $1 \mathrm{ft}$ with an echo sounder. Positions and depths were recorded simultaneously on a data logger while the boat traversed the reservoir at a rate that produced an average of 60 measurements per acre of reservoir surface. The GPS data were differentially corrected and then imported as point coverages into a geographic information system (GIS). It was not possible to collect continuous depth measurements for Emerson Brook Reservoir, Danvers Water Department, because the reservoir was too shallow for the echo sounder to record depths. Therefore, discrete, spatially referenced water-depth measurements were collected for Emerson Brook Reservoir.

Whenever possible, the spillway elevation of the reservoir supplied by the public water supplier was used as a reference location, if a reservoir's water level was below the spillway on the day of the survey. If the spillway elevation was not known, it was estimated from 1:25,000 USGS topographic maps. Outlines of the reservoirs were obtained by using 1:25,000 
Table 1. Massachusetts drinking-water-supply systems and associated reservoirs used to investigate factors affecting reservoir firm yield.

[Reservoir ID: identifier from figure 3. Firm Yield Estimator Model from Massachusetts Department of Environmental Protection, 1996. PWSID, Public Water Supply Identification Number; PALIS, Pond and Lake Identification System; DPW, Department of Public Works; SUASCO, Sudbury-AssabetConcord; - , PALIS code not available]

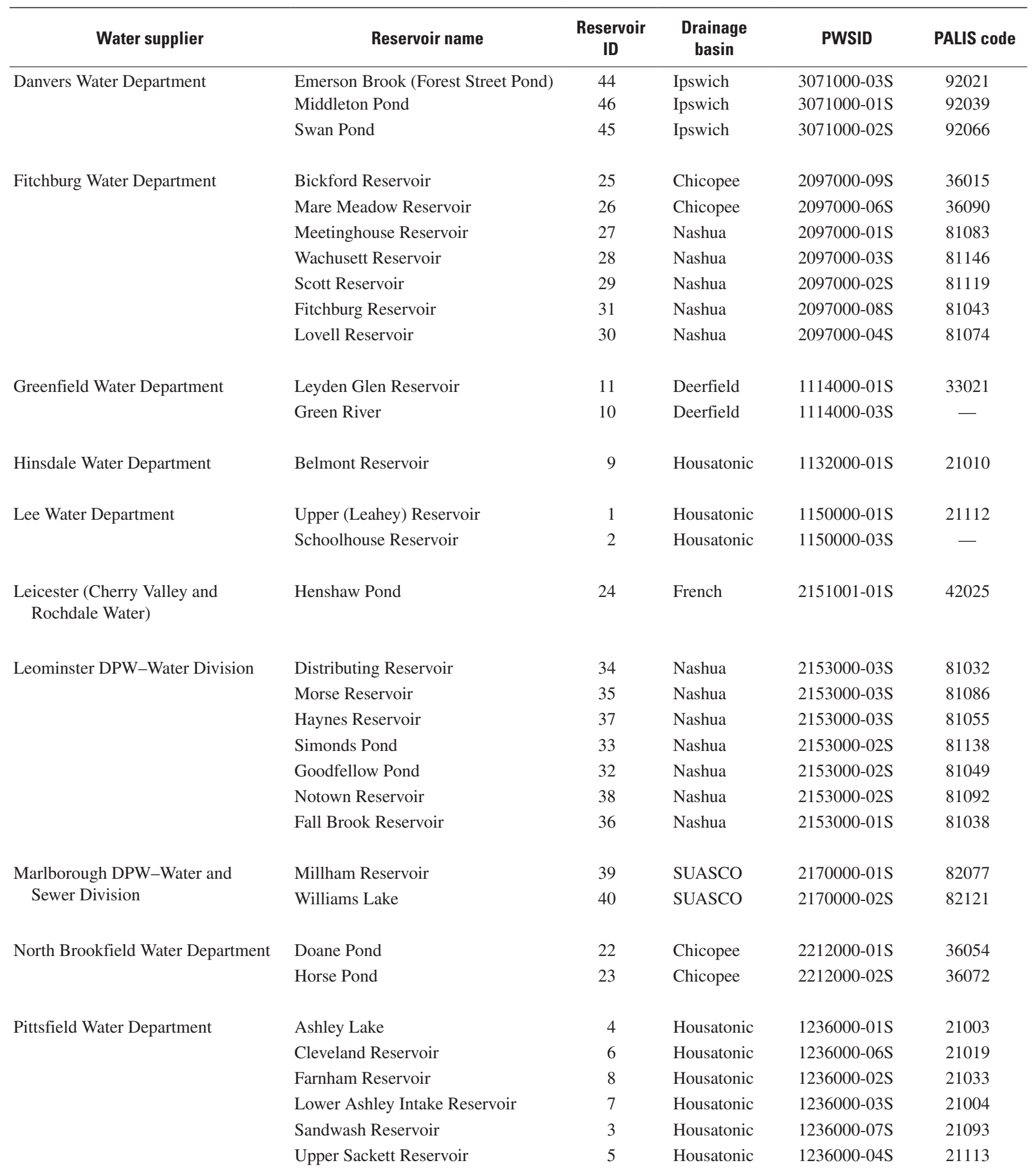


Table 1. Massachusetts drinking-water-supply systems and associated reservoirs used to investigate factors affecting reservoir firm yield.-Continued

[Reservoir ID: identifier from figure 3. Firm Yield Estimator Model from Massachusetts Department of Environmental Protection, 1996. PWSID, Public Water Supply Identification Number; PALIS, Pond and Lake Identification System; DPW, Department of Public Works; SUASCO, Sudbury-AssabetConcord; - - PALIS code not available]

\begin{tabular}{|c|c|c|c|c|c|}
\hline Water supplier & Reservoir name & $\begin{array}{c}\text { Reservoir } \\
\text { ID }\end{array}$ & $\begin{array}{c}\text { Drainage } \\
\text { basin }\end{array}$ & PWSID & PALIS code \\
\hline \multirow[t]{3}{*}{ Southbridge Water Department } & Hatchet Brook Reservoir \#3 & 19 & Quinebaug & 2287000-01S & 41038 \\
\hline & Hatchet Brook Reservoir \#5 & 17 & Quinebaug & $2287000-03 \mathrm{~S}$ & 41040 \\
\hline & Hatchet Pond & 20 & Quinebaug & $2287000-05 S$ & - \\
\hline \multirow[t]{2}{*}{ South Deerfield Water Supply District } & Roaring Brook Reservoir & 12 & Connecticut & 1074001-01S & 34125 \\
\hline & Whately Reservoir & 13 & Connecticut & $1074001-02 S$ & 34123 \\
\hline \multirow[t]{2}{*}{ Westfield Water Department } & Granville Reservoir & 15 & Westfield & $1329000-02 S$ & 32038 \\
\hline & Montgomery Reservoir & 14 & Westfield & 1329000-01S & 32074 \\
\hline \multirow{2}{*}{ Winchester Water Department } & North Reservoir & 43 & Mystic & $3344000-01 \mathrm{~S}$ & 71033 \\
\hline & South Reservoir & 41 & Mystic & $3344000-03 \mathrm{~S}$ & 71038 \\
\hline
\end{tabular}

USGS topographic maps and 1:5,000 black and white orthophotos (Office of Geographic and Environmental Information (MassGIS), 2005b).

Bathymetric contours were generated by using the TOPOGRID and LATTICECONTOUR commands in ARC/ INFO (Environmental Systems Research Institute, Inc., 1994) with the techniques developed by Hutchinson (1989). The usable storage and other characteristics determined for the reservoirs investigated during this study are summarized in table 3; bathymetric maps, with the exception of Emerson Brook Reservoir, and curves relating reservoir storage to reservoir surface area for each of the study reservoirs are included in the appendix.

\section{Required Releases}

The FYE model has the capability to account for monthly required releases of water from the reservoir to supplement flow in the stream reach below the reservoir; however, at the time of publication, none of the study reservoirs required releases for this purpose. Therefore, calculated firm yields presented in the report do not take into account the amount of water released to the downstream reach.

Although none of the reservoirs in the study area had release requirements, the inclusion of required releases in the reservoir water balance could result in more than one reservoir failure, even if no withdrawals for public supply are specified.
Therefore, a firm yield may not exist for some reservoirs if the release rate exceeds the reservoir's firm yield.

\section{Peak-Usage Factors}

The MassDEP (1996) guidance document uses an iterative procedure to determine the maximum rate of withdrawal that can be sustained during drought conditions. The firm yield may deplete all available storage for, at most, one month of the simulation but still satisfy the stated yield. For a given reservoir system, the withdrawal rate used at each iteration is adjusted by factors derived from user-specified withdrawal information to account for seasonal variations in water use. In this study, a set of monthly peak-usage factors was developed for each reservoir by averaging the monthly peak-usage factors determined from monthly withdrawals for the period 1997 through 2001. The monthly peak-usage factor was determined by dividing the monthly withdrawals by the average withdrawals for the year. This resulted in a monthly peak-usage factor for each month of the year for the period 1997 through 2001, from which the average monthly peak-usage factor was determined. The firm yield is sensitive to changes in the demand patterns. For example, when demand patterns are in phase with seasonal streamflow fluctuations (peak demands occur during seasons with peak flows), the firm yield will be higher than when demand patterns are out of phase with seasonal streamflow fluctuations (peak demands occur when flows are at a minimum). In a few cases, withdrawal rates had recently 


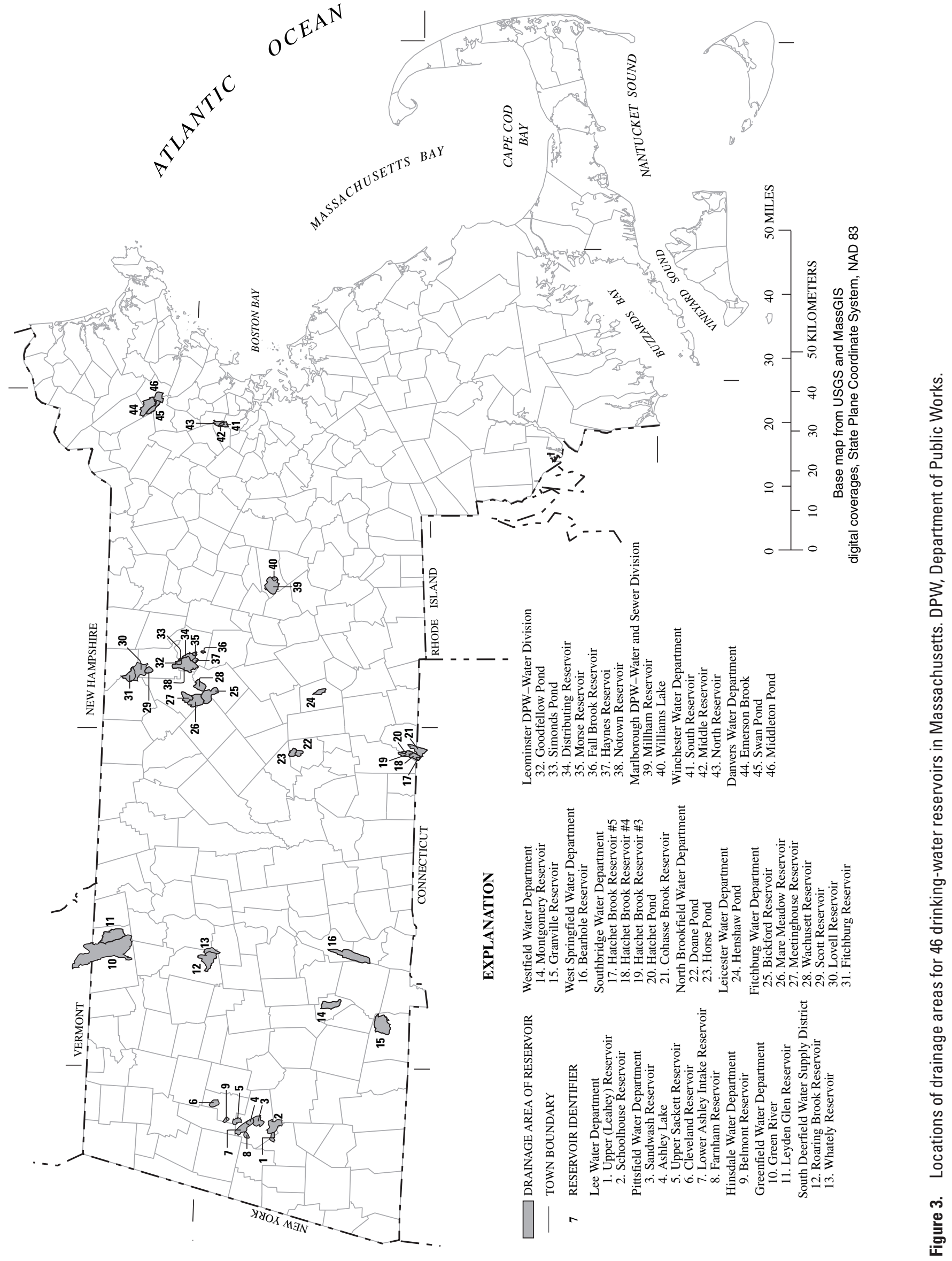


Table 2. Reservoir and drainage-basin characteristics for 70 Massachusetts drinking-water-supply reservoirs.

[Surface area and total drainage area determined from 1:125,000-scale USGS topographic maps. DPW, Department of Public Works; mi², square mile]

\begin{tabular}{|c|c|c|c|c|c|c|c|}
\hline Water supplier & Reservoir name & $\begin{array}{c}\text { Surface } \\
\text { area } \\
\left(\mathrm{mi}^{2}\right)\end{array}$ & $\begin{array}{l}\text { Drainage } \\
\text { area, } \\
\text { excluding } \\
\text { surface } \\
\text { area }\left(\mathrm{mi}^{2}\right)\end{array}$ & $\begin{array}{l}\text { Sand and } \\
\text { gravel in } \\
\text { drainage } \\
\text { basin } \\
\left(\mathrm{mi}^{2}\right)\end{array}$ & $\begin{array}{l}\text { Ratio of } \\
\text { drainage } \\
\text { area to } \\
\text { surface } \\
\text { area }\end{array}$ & $\begin{array}{c}\text { Percentage } \\
\text { of drainage } \\
\text { basin that is } \\
\text { sand } \\
\text { and gravel }\end{array}$ & $\begin{array}{c}\text { Percentage } \\
\text { of reservoir } \\
\text { perimeter in } \\
\text { contact with } \\
\text { sand and } \\
\text { gravel }\end{array}$ \\
\hline Ashburnham Water Department & Upper Naukeag Lake & 0.477 & 1.42 & 0.00 & 3.0 & 0.00 & 0 \\
\hline Concord Water Department & Nagog Pond & .434 & .77 & .08 & 1.8 & 7.0 & 10 \\
\hline \multirow[t]{2}{*}{ Danvers Water Department } & $\begin{array}{l}\text { Emerson Brook } \\
\quad(\text { Forest Street Pond) }\end{array}$ & .305 & 3.14 & .07 & 10 & 2.1 & 0 \\
\hline & Middleton Pond & .201 & 2.63 & .11 & 13 & 3.9 & 10 \\
\hline \multirow{9}{*}{ Fitchburg Water Department } & Mare Meadow Reservoir & .375 & 2.73 & .00 & 7.3 & .01 & 5 \\
\hline & Meetinghouse Reservoir & .236 & 1.32 & .00 & 5.6 & .00 & 0 \\
\hline & Wachusett Reservoir & .201 & 1.63 & .06 & 8.1 & 3.0 & 80 \\
\hline & Scott Reservoir & .052 & .74 & .00 & 14 & .00 & 0 \\
\hline & Fitchburg Reservoir & .234 & 1.92 & .05 & 8.2 & 2.4 & 0 \\
\hline & Shattuck Reservoir & .001 & 3.96 & .00 & 4,000 & .00 & 20 \\
\hline & Lovell Reservoir & .055 & 5.34 & .06 & 97 & 1.2 & 0 \\
\hline & Falulah Reservoir & .005 & .02 & .00 & 3.0 & .00 & 0 \\
\hline & Overlook Reservoir & .014 & .07 & .00 & 5.5 & .00 & 0 \\
\hline Hinsdale Water Department & Belmont Reservoir & .017 & .40 & .00 & 23 & .00 & 0 \\
\hline Hudson Water Department & Gates Pond & .110 & .26 & .03 & 2.3 & 9.5 & 5 \\
\hline \multirow[t]{2}{*}{ Lee Water Department } & Upper (Leahey) Reservoir & .069 & .63 & .00 & 9.1 & .00 & 0 \\
\hline & Schoolhouse Reservoir & .061 & 2.85 & .00 & 46.8 & .00 & 0 \\
\hline $\begin{array}{l}\text { Leicester (Cherry Valley and } \\
\text { Rochdale Water) }\end{array}$ & Henshaw Pond & .057 & .88 & .02 & 15 & 2.2 & 0 \\
\hline
\end{tabular}


Table 2. Reservoir and drainage-basin characteristics for 70 Massachusetts drinking-water-supply reservoirs-Continued.

[Surface area and total drainage area determined from 1:125,000-scale USGS topographic maps. DPW, Department of Public Works; mi², square mile]

\begin{tabular}{|c|c|c|c|c|c|c|c|}
\hline Water supplier & Reservoir name & $\begin{array}{c}\text { Surface } \\
\text { area } \\
\left(\mathrm{mi}^{2}\right)\end{array}$ & $\begin{array}{l}\text { Drainage } \\
\text { area, } \\
\text { excluding } \\
\text { surface } \\
\text { area }\left(\mathrm{mi}^{2}\right)\end{array}$ & $\begin{array}{c}\text { Sand and } \\
\text { gravel in } \\
\text { drainage } \\
\text { basin } \\
\left(\mathrm{mi}^{2}\right)\end{array}$ & $\begin{array}{l}\text { Ratio of } \\
\text { drainage } \\
\text { area to } \\
\text { surface } \\
\text { area }\end{array}$ & $\begin{array}{c}\text { Percentage } \\
\text { of drainage } \\
\text { basin that is } \\
\text { sand } \\
\text { and gravel }\end{array}$ & $\begin{array}{c}\text { Percentage } \\
\text { of reservoir } \\
\text { perimeter in } \\
\text { contact with } \\
\text { sand and } \\
\text { gravel }\end{array}$ \\
\hline \multirow{5}{*}{$\begin{array}{l}\text { Leominster DPW-Water } \\
\text { Division }\end{array}$} & Distributing Reservoir & .007 & 1.85 & .19 & 270 & 10 & 90 \\
\hline & Simonds Pond & .009 & 4.82 & .35 & 530 & 7.2 & 40 \\
\hline & Goodfellow Pond & .006 & 4.83 & .35 & 750 & 7.2 & 0 \\
\hline & Notown Reservoir & .375 & 4.05 & .23 & 11 & 5.1 & 0 \\
\hline & Fall Brook Reservoir & .137 & 1.21 & .00 & 8.8 & .00 & 0 \\
\hline Manchester Water Department & Gravelly Pond & .083 & .08 & .06 & .93 & 39 & 95 \\
\hline \multirow{2}{*}{$\begin{array}{l}\text { Marlborough DPW, Water and } \\
\text { Sewer Division }\end{array}$} & Millham Reservoir & .104 & 3.75 & .50 & 36 & 13 & 50 \\
\hline & Williams Lake & .108 & .25 & .00 & 2.3 & .00 & 0 \\
\hline \multirow{2}{*}{$\begin{array}{l}\text { North Brookfield Water } \\
\text { Department }\end{array}$} & Doane Pond & .043 & 1.67 & .00 & 37 & .00 & 0 \\
\hline & Horse Pond & .099 & .83 & .00 & 8.4 & .00 & 0 \\
\hline Pittsfield Water Department & Ashley Lake & .146 & .52 & .00 & 3.6 & .00 & 0 \\
\hline \multirow{3}{*}{$\begin{array}{l}\text { Braintree-Randolph-Holbrook } \\
\text { Tri-Town Water Board }\end{array}$} & Great Pond & .310 & 5.79 & 1.33 & 19 & 22 & 5 \\
\hline & Upper Reservoir & .312 & 5.53 & 2.50 & 18 & 43 & 50 \\
\hline & Richardi Reservoir & .083 & .17 & .17 & 2.1 & 65 & 40 \\
\hline Russell Water Department & Russell Reservoir (Black Brook) & .001 & 2.26 & .00 & 2,300 & .00 & 0 \\
\hline \multirow[t]{5}{*}{ Southbridge Water Department } & Hatchet Brook Reservoir \#3 & .037 & 2.38 & .03 & 65 & 1.1 & 0 \\
\hline & Hatchet Brook Reservoir \#4 & .108 & 2.14 & .03 & 20 & 1.2 & 0 \\
\hline & Hatchet Brook Reservoir \#5 & .047 & 1.10 & .01 & 23 & .74 & 0 \\
\hline & Hatchet Pond & .059 & .06 & .00 & 1.0 & .00 & 0 \\
\hline & Cohasse Brook Reservoir & .088 & 2.04 & .00 & 23 & .00 & 0 \\
\hline \multirow{2}{*}{$\begin{array}{l}\text { South Deerfield Water Supply } \\
\text { District }\end{array}$} & Roaring Brook Reservoir & .031 & 3.89 & .13 & 126 & 3.4 & 0 \\
\hline & Whately Reservoir & .003 & 5.15 & .13 & 1,700 & 2.6 & 0 \\
\hline
\end{tabular}


Table 2. Reservoir and drainage-basin characteristics for 70 Massachusetts drinking-water-supply reservoirs-Continued.

[Surface area and total drainage area determined from 1:125,000-scale USGS topographic maps. DPW, Department of Public Works; mi², square mile]

\begin{tabular}{|c|c|c|c|c|c|c|c|}
\hline Water supplier & Reservoir name & $\begin{array}{c}\text { Surface } \\
\text { area } \\
\left(\mathrm{mi}^{2}\right)\end{array}$ & $\begin{array}{l}\text { Drainage } \\
\text { area, } \\
\text { excluding } \\
\text { surface } \\
\text { area }\left(\mathrm{mi}^{2}\right)\end{array}$ & $\begin{array}{c}\text { Sand and } \\
\text { gravel in } \\
\text { drainage } \\
\text { basin } \\
\left(\mathrm{mi}^{2}\right)\end{array}$ & $\begin{array}{c}\text { Ratio of } \\
\text { drainage } \\
\text { area to } \\
\text { surface } \\
\text { area }\end{array}$ & $\begin{array}{c}\text { Percentage } \\
\text { of drainage } \\
\text { basin that is } \\
\text { sand } \\
\text { and gravel }\end{array}$ & $\begin{array}{c}\text { Percentage } \\
\text { of reservoir } \\
\text { perimeter in } \\
\text { contact with } \\
\text { sand and } \\
\text { gravel }\end{array}$ \\
\hline Wakefield Water Department & Crystal Lake & .128 & .13 & .03 & 1.0 & 10 & 20 \\
\hline Westfield Water Department & Montgomery Reservoir & .063 & 2.52 & .16 & 40 & 6.2 & 0 \\
\hline $\begin{array}{l}\text { West Springfield Water } \\
\text { Department }\end{array}$ & Bearhole Reservoir & .027 & 5.52 & 1.49 & 203 & 27 & 80 \\
\hline \multirow[t]{3}{*}{ Winchester Water Department } & Middle Reservoir & .082 & .20 & .00 & 2.5 & .00 & 0 \\
\hline & North Reservoir & .086 & .54 & .04 & 6.3 & 6.0 & 0 \\
\hline & South Reservoir & .113 & .65 & .00 & 5.8 & .00 & 0 \\
\hline \multirow[t]{5}{*}{ Worcester Water Department } & Holden Reservoir \#1 & .193 & 4.32 & .00 & 22 & .00 & 35 \\
\hline & Holden Reservoir \#2 & .081 & 5.17 & .00 & 64 & .00 & 15 \\
\hline & Kendall Reservoir & .279 & 1.44 & .15 & 5.2 & 8.7 & 20 \\
\hline & Kettle Brook Reservoir \#1 & .020 & 4.11 & .00 & 200 & .00 & 0 \\
\hline & Kettle Brook Reservoir \#2 & .046 & 3.05 & .00 & 67 & .00 & 0 \\
\hline
\end{tabular}

changed because treatment plants had been added or upgraded. Therefore, the peak-usage factors were determined on the basis of the most recent withdrawal data, which represented the expected activity in the near future.

\section{Precipitation and Evaporation}

Records of total precipitation, snowfall (liquid equivalent), and air temperature, formatted for use in the FYE model, were obtained from the MassDEP (2000) FYE Model v. 1.0 and used in the firm-yield estimations. The FYE model uses climate data for 42 meteorological stations in Massachusetts and adjacent states; these data originally were obtained from the National Climatic Data Center of the National Oceanic and Atmospheric Administration. Reporting periods range in length from 34 to 73 years and all begin no later than 1959 so as to include the 1960s drought-of-record. Locations of the stations relative to drainage basins for the study reservoirs are shown in figure 4. Firm-yield estimates for the study reservoirs were always made on the basis of records from the nearest meteorological station; therefore, only approximately half of the climate stations shown in figure 4 were used to compute firm yields for the study reservoirs.

Evaporation from reservoir surfaces was simulated by the FYE model by using mean monthly air-temperature data available as part of the meteorological records with the location (latitude and longitude) and elevation of the reservoir, as outlined in the method by Fennessey and Vogel (1996). Fennessey (1995) showed that firm-yield estimates computed with fixed mean monthly values for reservoir evaporation rates were essentially the same as the estimates computed with an evaporation time series of higher frequency. 


\section{Firm Yield and the Estimation of Firm Yield for Streamflow-Dominated Drinking-Water-Supply Reservoirs}

Table 3. Reservoir-specific properties for 46 Massachusetts drinking-water-supply reservoirs.

[Reservoir ID: identifier from figure 3. Altitudes are relative to NAD 83. DPW, Department of Public Works; ft, foot; Mgal; million gallons; —, reservoir storage is negligible]

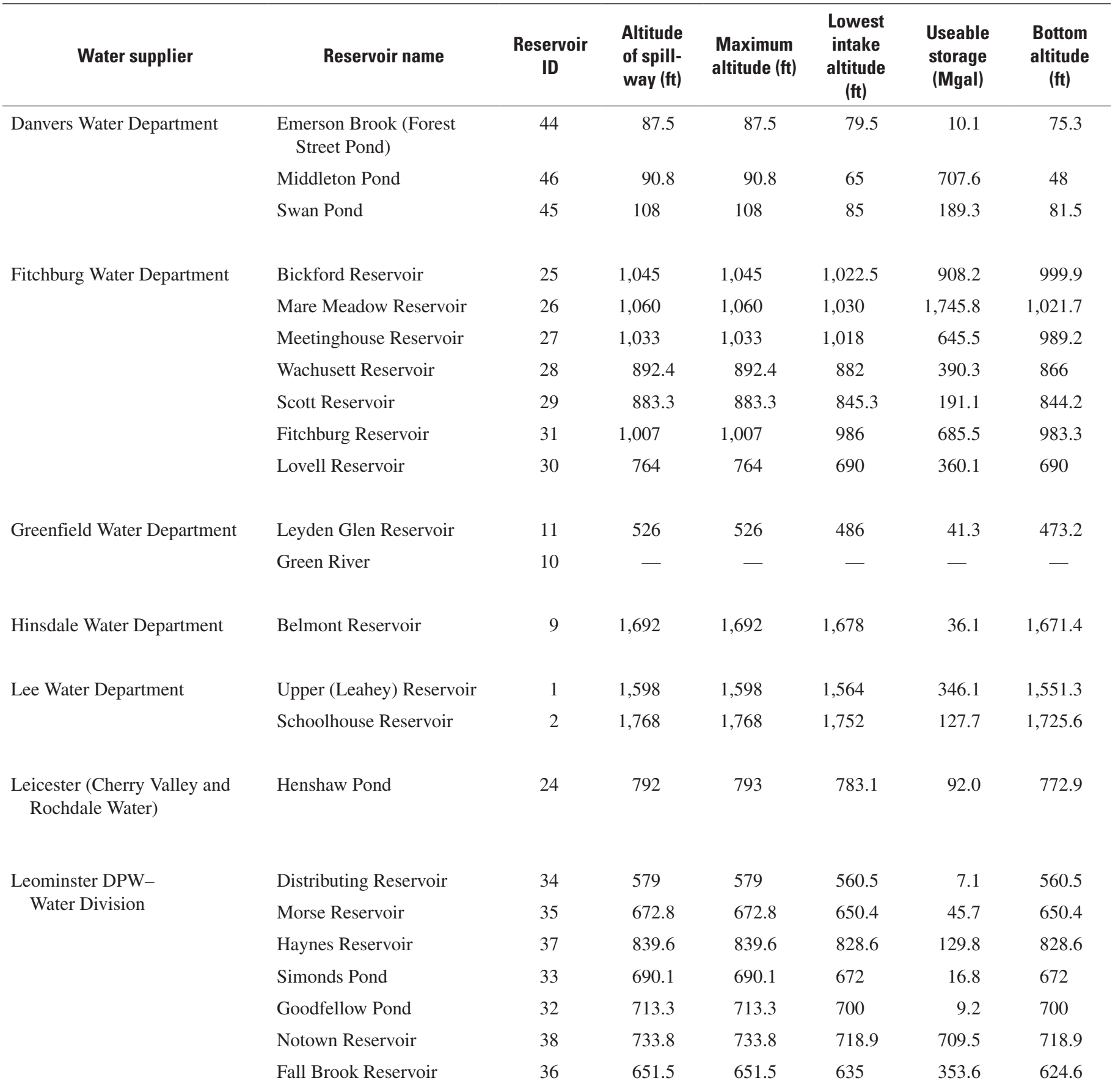


Table 3. Reservoir-specific properties for 46 Massachusetts drinking-water-supply reservoirs.-Continued

[Reservoir ID: identifier from figure 3. Altitudes are relative to NAD 83. DPW, Department of Public Works; ft, foot; Mgal; million gallons; —, reservoir storage is negligible]

\begin{tabular}{|c|c|c|c|c|c|c|c|}
\hline Water supplier & Reservoir name & $\begin{array}{l}\text { Reservoir } \\
\text { ID }\end{array}$ & $\begin{array}{l}\text { Altitude } \\
\text { of spill- } \\
\text { way (ft) }\end{array}$ & $\begin{array}{l}\text { Maximum } \\
\text { altitude (ft) }\end{array}$ & $\begin{array}{c}\text { Lowest } \\
\text { intake } \\
\text { altitude } \\
\text { (ft) }\end{array}$ & $\begin{array}{l}\text { Useable } \\
\text { storage } \\
\text { (Mgal) }\end{array}$ & $\begin{array}{l}\text { Bottom } \\
\text { altitude } \\
\text { (ft) }\end{array}$ \\
\hline \multirow{2}{*}{$\begin{array}{l}\text { Marlborough DPW- } \\
\text { Water and Sewer Division }\end{array}$} & Millham Reservoir & 39 & 236 & 236 & 214.2 & 313.3 & 212.9 \\
\hline & Williams Lake & 40 & ${ }^{1} 434$ & 437.8 & ${ }^{2}-$ & .0 & 408.4 \\
\hline \multirow{2}{*}{$\begin{array}{l}\text { North Brookfield Water } \\
\text { Department }\end{array}$} & Doane Pond & 22 & 896 & 896 & 883.1 & 42.6 & 883.1 \\
\hline & Horse Pond & 23 & 916 & 917 & 903 & 247.8 & 889 \\
\hline \multirow[t]{6}{*}{ Pittsfield Water Department } & Ashley Lake & 4 & 1,924 & 1,926 & $1,909.2$ & 472.8 & $1,871.7$ \\
\hline & Cleveland Reservoir & 6 & 1,435 & 1,439 & 1,385 & $1,827.2$ & $1,372.4$ \\
\hline & Farnham Reservoir & 8 & 1,585 & 1,587 & 1,525 & 478.1 & $1,513.4$ \\
\hline & Lower Ashley Intake & 7 & - & - & - & - & - \\
\hline & Sandwash Reservoir & 3 & 1,895 & $1,895.0$ & 1,864 & 257.9 & $1,863.3$ \\
\hline & Upper Sackett Reservoir & 5 & 1,520 & $1,520.0$ & $1,481.5$ & 164.8 & $1,470.2$ \\
\hline \multirow[t]{5}{*}{ Southbridge Water Department } & Hatchet Brook Reservoir \#3 & 19 & 678.1 & 680.1 & 662 & 88.8 & 660.5 \\
\hline & Hatchet Brook Reservoir \#4 & 18 & 705.6 & 707.6 & 694 & 265.4 & 686.4 \\
\hline & Hatchet Brook Reservoir \#5 & 17 & 746.4 & 748.4 & 723 & 178.5 & 718.2 \\
\hline & Hatchet Pond & 20 & 863 & 865 & 842 & 163.5 & 841.8 \\
\hline & Cohasse Brook Reservoir & 21 & 632 & 634 & 591 & 385.4 & 578.7 \\
\hline \multirow{2}{*}{$\begin{array}{l}\text { South Deerfield Water Supply } \\
\text { District }\end{array}$} & Roaring Brook Reservoir & 12 & 538 & 541.5 & 490 & 176.4 & 488.7 \\
\hline & Whately Reservoir & 13 & 424 & 427 & 406 & 11.4 & 399.6 \\
\hline \multirow[t]{2}{*}{ Westfield Water Department } & Granville Reservoir & 15 & 591 & 592 & 527 & 665.6 & 527 \\
\hline & Montgomery Reservoir & 14 & 918 & 918 & 888.7 & 209.1 & 888.7 \\
\hline $\begin{array}{l}\text { West Springfield Water } \\
\text { Department }\end{array}$ & Bearhole Reservoir & 16 & 165 & 165 & 140.5 & 92.5 & 136.7 \\
\hline \multirow[t]{3}{*}{ Winchester Water Department } & Middle Reservoir & 42 & 168.2 & 168.2 & 157.6 & 123.2 & 154.3 \\
\hline & North Reservoir & 43 & 156.3 & 156.3 & 140.9 & 252.8 & 123.9 \\
\hline & South Reservoir & 41 & 165.3 & 165.3 & 146.8 & 419.4 & 120.2 \\
\hline
\end{tabular}

${ }^{1}$ Elevation of overflow gate.

${ }^{2}$ Water availability from spillway only. 


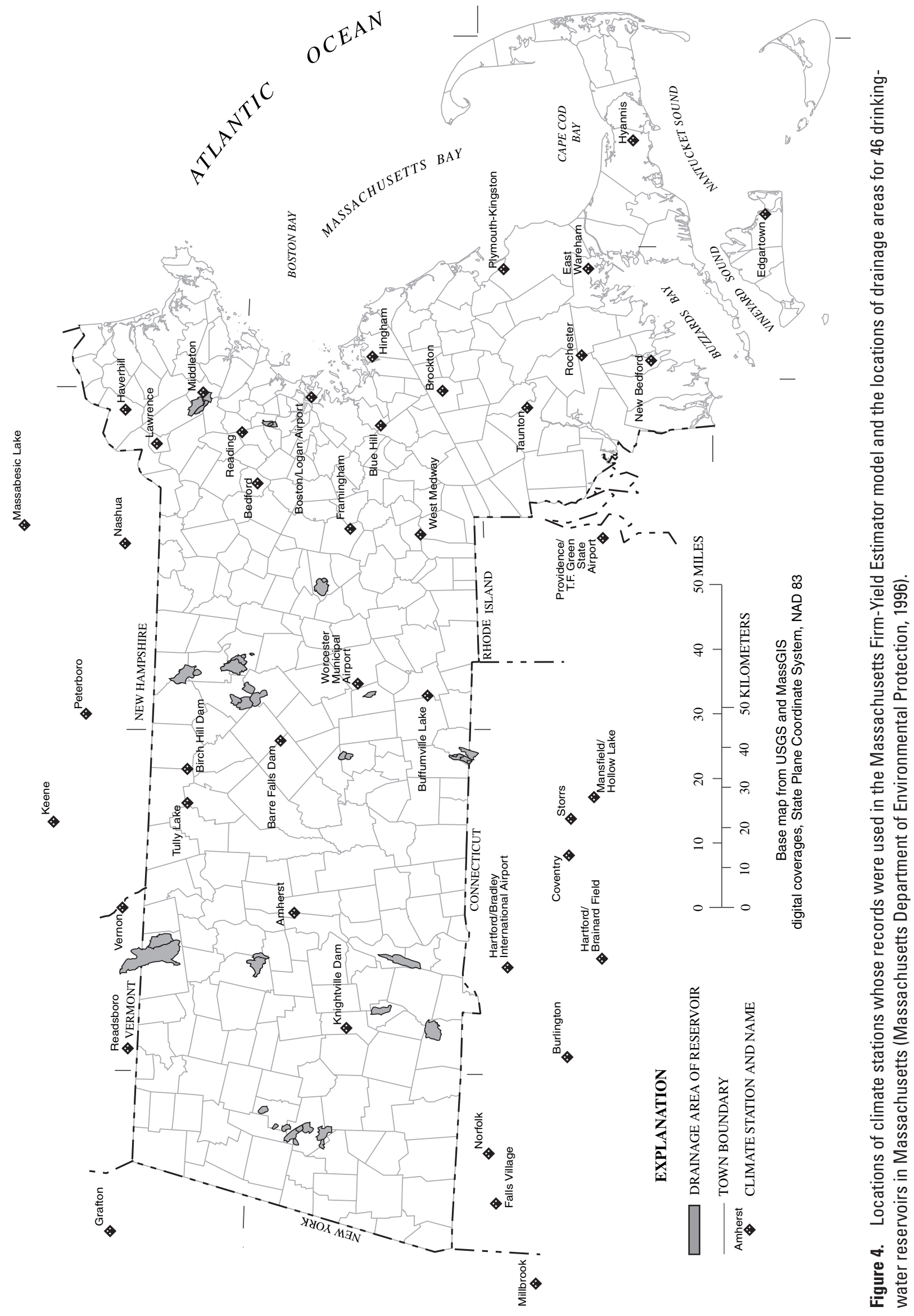




\section{Estimation of Surface-Water Inflows}

Surface-water inflows are the most important sources of water for the reservoirs examined in this study. Continuous estimates of inflows during the period of record that includes the 1960s drought-of-record are needed as input to the FYE model. With the exception of a few large drinking-water-supply systems in Massachusetts, however, these data are seldom available. Therefore, the FYE model includes a method for calculating surface-water inflow to a reservoir by using continuous daily data from a streamflow-gaging station and assuming that the probability of a flow on a given day at the gaged site is equivalent to the probability of flow at the ungaged site. The method was developed by Fennessey (1994) and is referred to as the QPPQ method. The term QPPQ is derived from the method used to determine streamflow at an ungaged site. First, the record of streamflow at the gaged site $(\mathrm{Q})$ is used to construct a flow-duration curve, which represents the probability of exceedence $(\mathrm{P})$ for each unique streamflow value in the record. Then the assumption is made that the probability of exceeding a flow at the gaged site is equivalent to the probability of exceeding a flow at the ungaged site $(\mathrm{P})$. Lastly, the equivalent exceedence probabilities and basin characteristics from the ungaged site are used to estimate streamflow $(\mathrm{Q})$. Because this method has not been extensively tested or widely applied, several experiments were performed to investigate the accuracy and reproducibility of the method.

\section{QPPQ method}

The QPPQ method uses an existing streamflow record from a monitored (gaged) site with an appropriate time period to develop a flow-duration curve (FDC), which provides exceedence probabilities, $P$, for the range of daily flows in the record. The flow probability, $P_{q}$, for any given day is determined and is considered equivalent to the flow probability estimated for an ungaged site (fig. 5). Equation 3 combines $P_{q}$ with three regional parameters $\xi$, $\alpha$, and $\kappa$ to give the flow value $q_{p}$ at the ungaged site (MassDEP, 1996):

$$
q_{p}=\xi+\frac{\alpha}{\kappa}\left[1-P_{q}^{k}\right]
$$

The three FDC parameters are simple exponential functions of climate, soil, and basin characteristics determined from a multivariate regression of 166 streamflow-gaging stations in the northeast and mid-Atlantic U.S. (Fennessey, 1994):

$$
\begin{aligned}
& \xi=\exp \left[-9.97+0.0895 \ln ^{2}(\text { AREA })+0.982 \ln (\mathrm{SOIL})+2.22 \ln (\mathrm{PREC})\right]-1, \\
& \alpha=\exp [-8.33+1.03 \ln (\mathrm{AREA})+2.06 \ln (\mathrm{PREC})+0.473 \ln (\mathrm{SOIL})], \text { and } \\
& \kappa=-0.0632 \ln (\mathrm{B}-\mathrm{ELEV})+0.350 \ln (\mathrm{SOIL})+0.169 \ln (\mathrm{SNOW})-0.0528 \ln (\mathrm{C}-\mathrm{SLOPE})+0.410 \ln (\mathrm{PREC})-1,
\end{aligned}
$$

where

$\ln ()=$ natural logarithm of the argument within the parentheses,

$\exp []=$ base $e$ exponent (inverse logarithm) of the argument within the bracket,

AREA = total area supplying water to the reservoir (including the surface area of the reservoir), in square miles,

SOIL = maximum amount of precipitation retained by soil in the drainage basin, in inches,

PREC = average annual rainfall, in inches,

SNOW = average annual snowfall, in inches,

B-ELEV = average elevation of the drainage basin, in feet above mean sea level, and

$\mathrm{C}-\mathrm{SLOPE}=$ mean channel slope, in feet per mile. 


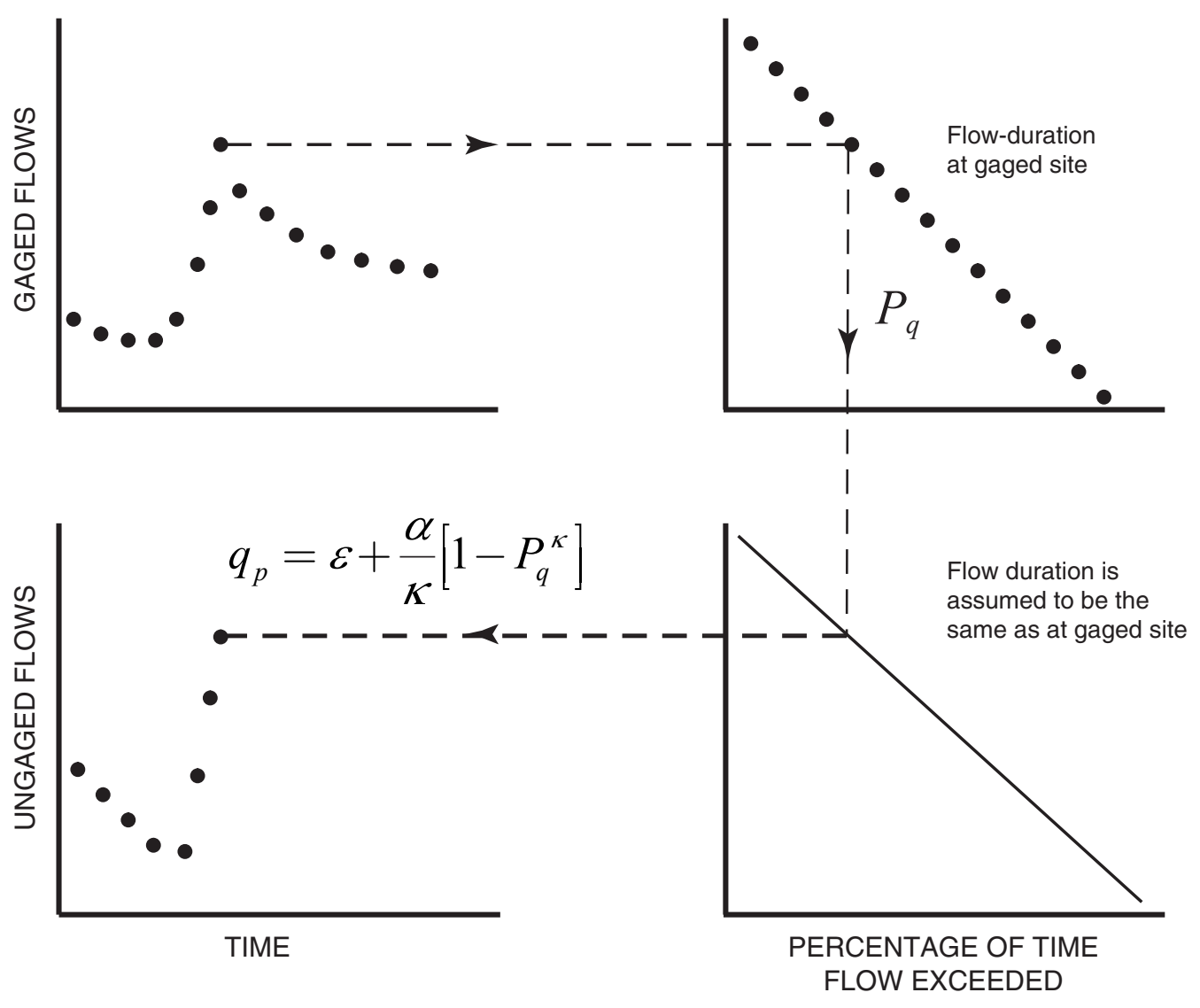

Figure 5. Description of the QPPO method, which estimates daily streamflow at an ungaged location by equating the exceedence probability of a given flow at the gaged location with the exceedence probability at the ungaged location (from Fennessey, 1994).

In this study, AREA was determined by use of the USGS StreamStats v. 2.0 program (Ries and others, 2000). This program provides streamflow statistics and basin characteristics for most streams in Massachusetts by using a GIS data layer consisting of drainage-basin boundaries for about 2,300 locations on Massachusetts streams, together with a digital elevation model (DEM) based on the elevations shown on 1:125,000-scale USGS topographic quadrangle maps. The USGS StreamStats program (Ries and others, 2000) was used to delineate the drainage basin, inclusive of the reservoir. The contributing drainage area to the reservoir (AREA) was determined by subtracting the surface area of the reservoir, determined at the same scale, from the total area of the drainage basin.

Values for SOIL were estimated by methods described in the Natural Resources Conservation Service's (NRCS) Technical Release 55 (TR-55) manual (Natural Resources Conservation Service, 1986). The digital drainage-basin boundaries for the study reservoirs were intersected with digital soil maps and digital land-use data layers (Office of Geographic and Environmental Information (MassGIS, 2005a). The resulting coverage was used to determine the percentage of each soil and land-cover type within the drainage basin of the reservoir. When digital soils maps were not available, appropriate sections of NRCS county soils maps were digitized and converted to data layers. Each combination of soil group and land cover was assigned a NRCS runoff-curve number, which indicates the expected runoff for a given amount of rainfall. A composite runoff-curve number $(\mathrm{CN})$ was then calculated by multiplying the fraction of the basin corresponding to a given runoff-curve number by that number and adding the weighted runoff-curve numbers. Finally, SOIL, in inches, was estimated from the $\mathrm{CN}$ by the use of the following equation (Natural Resources Conservation Service, 1986):

$$
\mathrm{SOIL}=\frac{1,000}{C N}-10,
$$

Precipitation and snowfall data for 25 meteorological stations in Massachusetts were obtained from the National Climatic Data Center (NCDC) of the National Oceanic and 
Atmospheric Administration (NOAA). Data from the closest station to the drainage-basin boundary for the reservoir were used to compute PREC and SNOW. Values for C-SLOPE and B-ELEV were determined by using a DEM based on elevations shown on 1:25,000-scale USGS topographic quadrangle maps. B-ELEV was estimated by the use of a DEM in conjunction with the drainage-basin boundaries already obtained from StreamStats for the reservoirs. C-SLOPE was estimated for each tributary stream supplying a reservoir by measuring the length of the stream on USGS topographic maps and dividing that length by the change in elevation (table 4).

\section{Model Sensitivity to Flow-Duration-Curve Characteristics}

The relative importance of the six climate, soil, and basin characteristics (AREA, SOIL, PREC, SNOW, B-ELEV, and C-SLOPE) used to calculate $\alpha, \kappa$, and $\xi$ was examined by systematically increasing and decreasing the value for each of these characteristics individually over the range of -90 percent to +100 percent of the initial value. The QPPQ method was then used to calculate the resultant change in streamflow, for 90-, 50-, and 10-percent exceedence probabilities. Results of the analyses are plotted in figures $6 A-6 D$, which depict the percent change in streamflow resulting from systematic changes in each basin characteristic for four of the study reservoirs: Granville Reservoir, Westfield Water Department; Belmont Reservoir, Hinsdale Water Department; Hatchet Pond, Southbridge Water Department; and Millham Reservoir, Marlborough Department of Public Works. The drainage areas of these reservoirs ranged in size from $0.24 \mathrm{mi}^{2}$ to $5.25 \mathrm{mi}^{2}$, and their average drainage area was representative of the average drainage area determined from the complete set of study reservoirs (table 4); however, two of the selected reservoirs have drainage areas less than the smallest drainage area used to develop the relations in equations 4-6. The responses represent the relative effects of measurement or estimation errors associated with each characteristic; however, the errors in estimating the values of most of the characteristics are unlikely to exceed 50 percent.

Increasing or decreasing values for SNOW, B-ELEV, and C-SLOPE had little or no effect on calculated streamflows at the 90- and 50-percent exceedence probabilities for all reservoirs tested (figs. 6A-6D). At the 10-percent exceedence probability, streamflow changed slightly (generally less than 10 percent even for the largest changes in the variable value) for both negative and positive changes in SNOW, B-ELEV, and C-SLOPE.

Streamflow exhibited the greatest sensitivity to PREC, and that sensitivity increased as flows decreased. For example, decreasing the value by 25 percent for PREC in the FDC equation for the Granville Reservoir drainage basin (Westfield Water Department) decreased flow by about 38 percent at the 10-percent flow exceedence, and more than 80 percent at the 90-percent flow exceedence (fig. 6A). Increasing the value for PREC by 25 percent resulted in a 40-percent increase in flow at the 10-percent flow exceedence, and a 100-percent increase in flow at the 90-percent flow exceedence. At the 10 -percent flow exceedence, the model predicted very small flows when the value for PREC was reduced by more than 25 percent of the initial value. Similar effects and ranges of sensitivity to PREC were noted for all reservoirs tested (figs. 6B-6D). A 25-percent smaller PREC value is lower than the average annual precipitation values reported for any Massachusetts monitoring stations; therefore, an error in the monthly precipitation record of this magnitude is considered unlikely. Nevertheless, small changes in PREC can influence the estimation of streamflow more than large changes in most of the other variables. At the 90-percent exceedence probability, SOIL was the second most sensitive variable for all four reservoirs. For the 10- and 50-percent exceedences, streamflow is sensitive to values of SOIL and AREA (see figs. $6 B-6 D)$.

Unusual effects were obtained when the value for AREA was decreased at the Belmont Reservoir and at Hatchet Pond (fig. $6 B$ and $6 C$ ). Each of these reservoirs had a drainage area less than $1 \mathrm{mi}^{2}$. For these reservoirs, the streamflow increased during one or more successive decreases in drainage area.

Flows into Hatchet Pond at the 10-percent flow exceedence increased only when decreases in drainage area were large. Small changes in drainage area at the 90-percent flow exceedence, however, caused flows into both reservoirs to increase. This response reflected the fact that the regression equations were not developed on the basis of small drainage areas (less than $1.5 \mathrm{mi}^{2}$ ). In addition, whereas the observed changes are great when expressed as percentages of the initial values, the actual changes in the streamflow values, even at the 90-percent flow exceedence, are very small.

\section{Prediction of Flow-Duration Curves}

The simulation accuracy of the QPPQ method was evaluated by simulating flow at two USGS streamflowgaging stations from long-term records at six other USGS streamflow-gaging stations. The eight stations used in this analysis were selected because they have minimally altered flows (by surface-water regulation, such as diversion or augmentation of streamflow, or by base-flow reduction resulting from ground-water pumping). Criteria for selection of these streamflow-monitoring stations are described by Armstrong and others (2004). In addition to their status as minimally altered streams, the stations were selected on the basis of their differences in selected drainage-basin characteristics and the distance of the reference streamflowmonitoring station from the station whose record was to be simulated by the QPPQ method (table 5). 
Table 4. Climate, soil, and basin characteristics for 46 Massachusetts drinking-water-supply reservoirs.

[Reservoir ID: identifier from figure 3. Altitudes are relative to NAD 83. AREA, reservoir drainage area plus surface area; PREC, average annual precipitation; SNOW, average annual snowfall; SOIL, maximum soil retention; B-ELEV, average drainage basin altitude; C-SLOPE, mean channel slope; DPW, Department of Public Works; ft, foot; ft/mi, foot per mile; in., inch; in/yr; inch per year; $\mathrm{mi}^{2}$, square mile]

\begin{tabular}{|c|c|c|c|c|c|c|c|c|}
\hline $\begin{array}{l}\text { Water } \\
\text { supplier }\end{array}$ & $\begin{array}{l}\text { Reservoir } \\
\text { name }\end{array}$ & $\begin{array}{l}\text { Reservoir } \\
\text { ID }\end{array}$ & $\begin{array}{c}\text { AREA } \\
\left(\mathrm{mi}^{2}\right)\end{array}$ & $\begin{array}{l}\text { PREC } \\
\text { (in/yr) }\end{array}$ & $\begin{array}{l}\text { SNOW } \\
\text { (in/yr) }\end{array}$ & $\begin{array}{l}\text { SOIL } \\
\text { (in.) }\end{array}$ & $\begin{array}{l}\text { B-ELEV } \\
(\mathrm{ft})\end{array}$ & $\begin{array}{c}\text { C-SLOPE } \\
(\mathrm{ft} / \mathrm{mi})\end{array}$ \\
\hline \multirow[t]{3}{*}{$\begin{array}{r}\text { Danvers Water } \\
\text { Department }\end{array}$} & $\begin{array}{l}\text { Emerson Brook (Forest } \\
\text { Street Pond) }\end{array}$ & 44 & 3.44 & 43.07 & 43.68 & 7.13 & 114.68 & 18.1 \\
\hline & Middleton Pond & 46 & 1.53 & 43.07 & 43.68 & 4.90 & 120.23 & 33.0 \\
\hline & Swan Pond & 45 & 1.30 & 43.07 & 43.68 & 5.13 & 124.18 & 2.2 \\
\hline \multirow{4}{*}{$\begin{array}{c}\text { Fitchburg Water } \\
\text { Department }\end{array}$} & Bickford Reservoir & 25 & 3.25 & 40.65 & 59.26 & 9.32 & $1,247.15$ & 127.9 \\
\hline & Mare Meadow Reservoir & 26 & 3.11 & 40.65 & 59.26 & 8.19 & $1,149.07$ & 190.9 \\
\hline & Meetinghouse Reservoir & 27 & 1.56 & 40.65 & 59.26 & 12.98 & $1,103.29$ & 167.0 \\
\hline & Wachusett Reservoir & 28 & 1.83 & 40.65 & 59.26 & 8.34 & $1,155.73$ & 592.0 \\
\hline \multirow{2}{*}{$\begin{array}{l}\text { Greenfield Water } \\
\text { Department }\end{array}$} & Leyden Glen Reservoir & 11 & 5.18 & 43.54 & 56.70 & 9.77 & 949.60 & 173.3 \\
\hline & Green River & 10 & 20.19 & 43.54 & 56.70 & 6.56 & 811.27 & 39.7 \\
\hline $\begin{array}{l}\text { Hinsdale Water } \\
\text { Department }\end{array}$ & Belmont Reservoir & 9 & .42 & 45.15 & 51.84 & 5.64 & $1,906.75$ & 885.0 \\
\hline $\begin{array}{l}\text { Lee Water } \\
\quad \text { Department }\end{array}$ & Upper (Leahey) Reservoir & 1 & .70 & 45.15 & 51.84 & 5.04 & $1,790.43$ & 347.0 \\
\hline \multirow{7}{*}{$\begin{array}{l}\text { Leominster DPW- } \\
\text { Water Division }\end{array}$} & Distributing Reservoir & 34 & 1.15 & 42.33 & 57.73 & 5.64 & 823.08 & 180.0 \\
\hline & Morse Reservoir & 35 & .30 & 42.33 & 57.73 & 5.63 & 785.08 & 580.0 \\
\hline & Haynes Reservoir & 37 & .44 & 42.33 & 57.73 & 4.39 & 877.86 & 289.0 \\
\hline & Simonds Pond & 33 & .19 & 42.33 & 57.73 & 6.27 & 834.44 & 111.0 \\
\hline & Goodfellow Pond & 32 & .41 & 42.33 & 57.73 & 6.27 & 834.38 & 118.0 \\
\hline & Notown Reservoir & 38 & 4.42 & 42.33 & 57.73 & 6.18 & 840.04 & 138.0 \\
\hline & Fall Brook Reservoir & 36 & 1.35 & 42.33 & 57.73 & 5.52 & 795.33 & 162.0 \\
\hline
\end{tabular}


Table 4. Climate, soil, and basin characteristics for 46 Massachusetts drinking-water-supply reservoirs.—Continued

[Reservoir ID: identifier from figure 3. Altitudes are relative to NAD 83. AREA, reservoir drainage area plus surface area; PREC, average annual precipitation; SNOW, average annual snowfall; SOIL, maximum soil retention; B-ELEV, average drainage basin altitude; C-SLOPE, mean channel slope; DPW, Department of Public Works; ft, foot; ft/mi, foot per mile; in., inch; in/yr; inch per year; $\mathrm{mi}^{2}$, square mile]

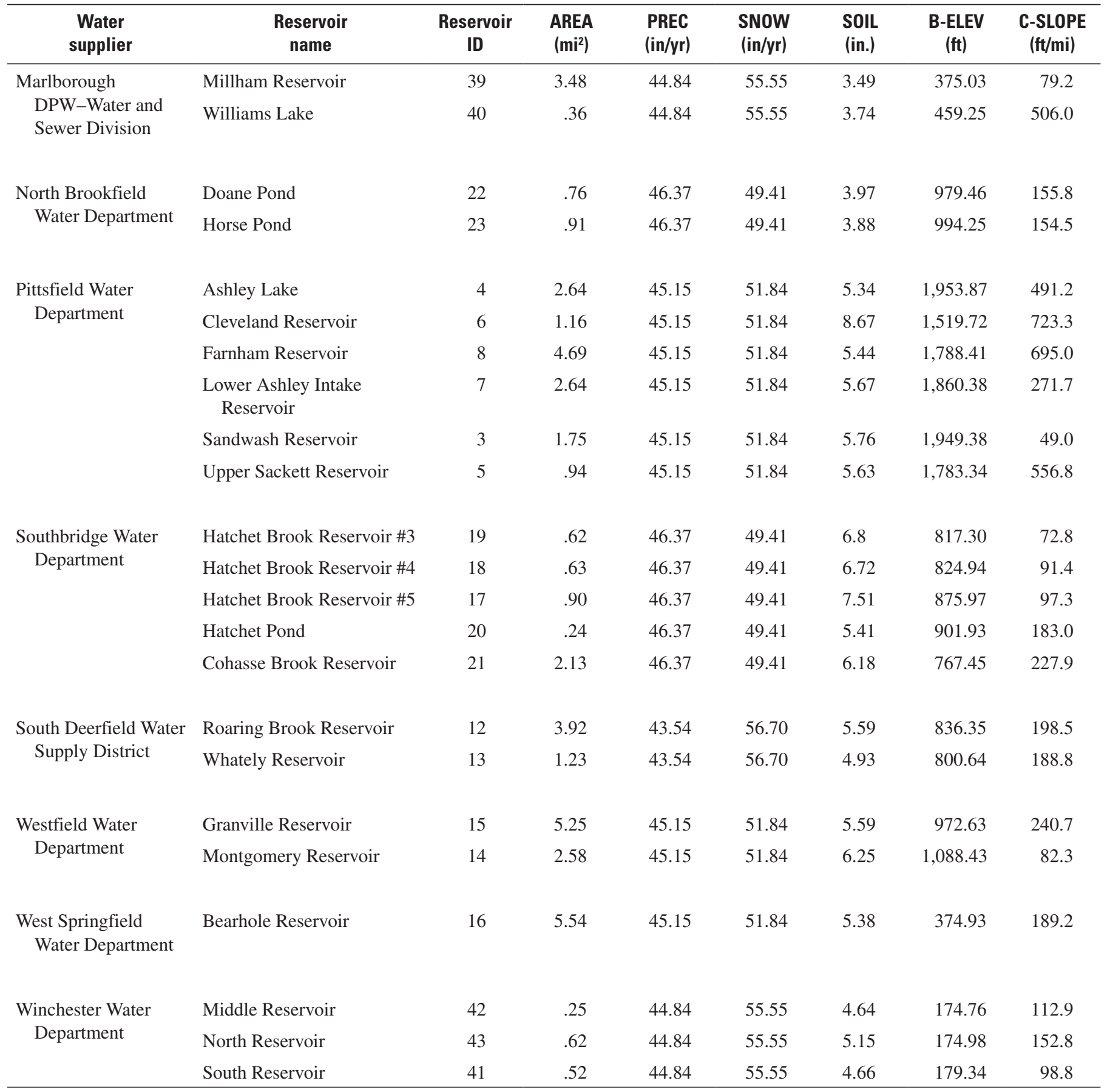


A.

Granville Reservoir (no. 15 on fig. 3) at 10-percent exceedence probability

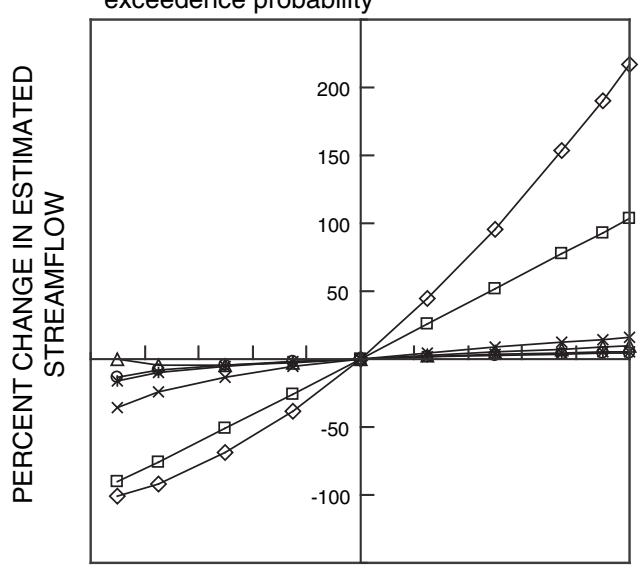

Granville Reservoir at 50-percent exceedence probability

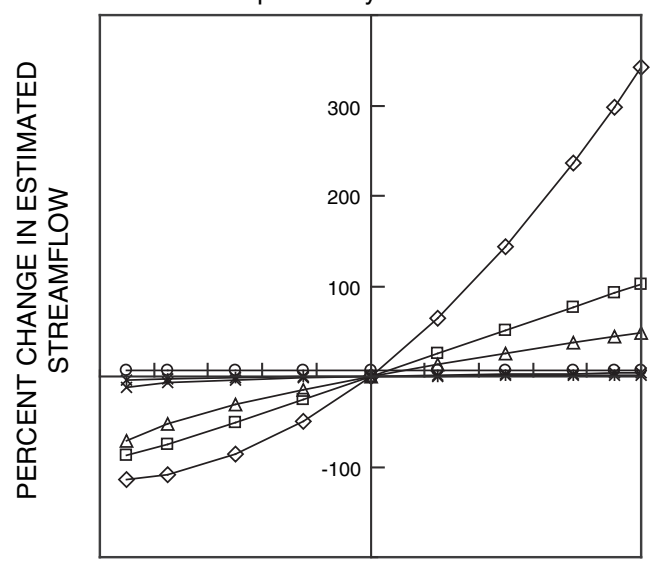

Granville Reservoir at 90-percent exceedence probability

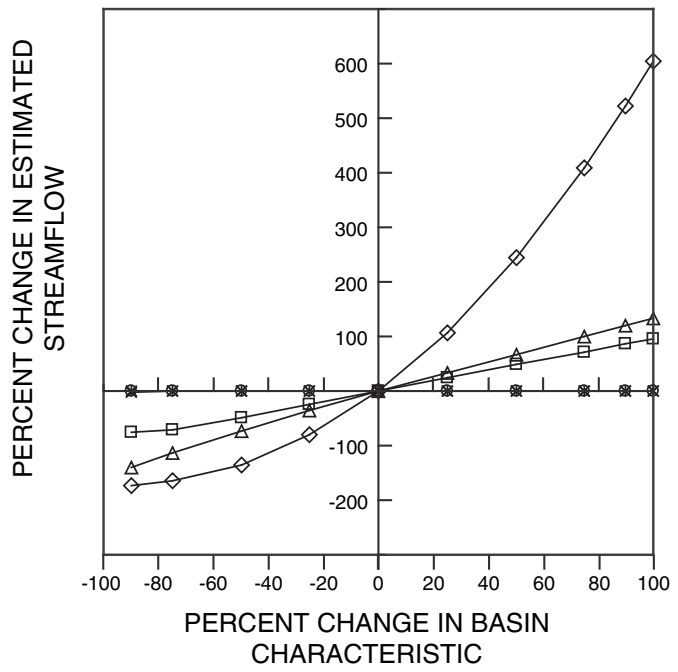

B.

Belmont Reservoir (no. 9 on fig. 3) at 10-percent exceedence probability

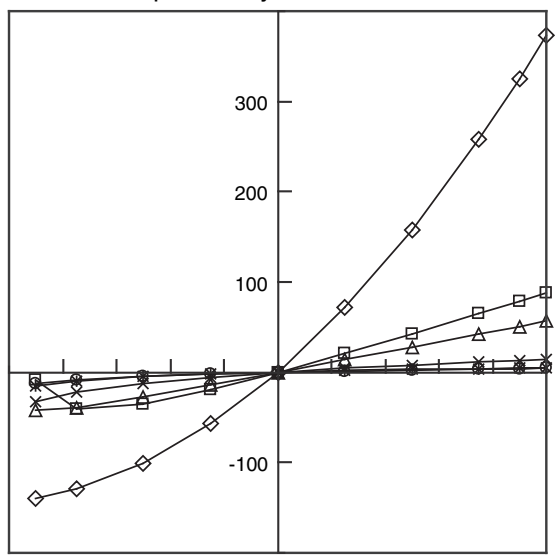

\section{EXPLANATION}

$\diamond$ PREC
$\square$ AREA
$\triangle$ SOIL
$*$ SNOW
$*$ B-ELEV
$\bullet-$ C-SLOPE

Belmont Reservoir at 50-percent exceedence probability

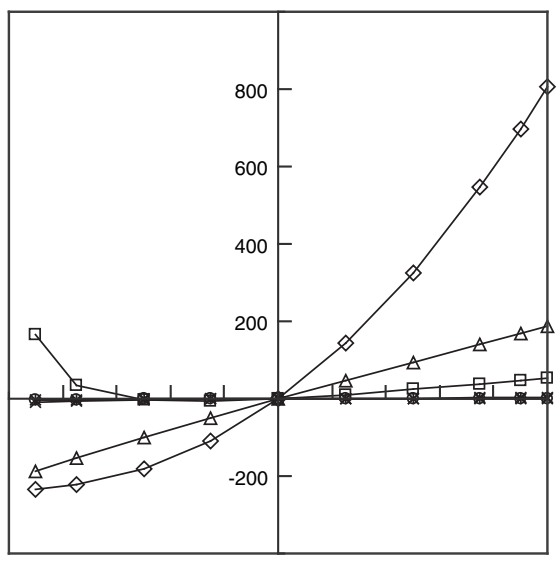

Belmont Reservoir at 90-percent exceedence probability

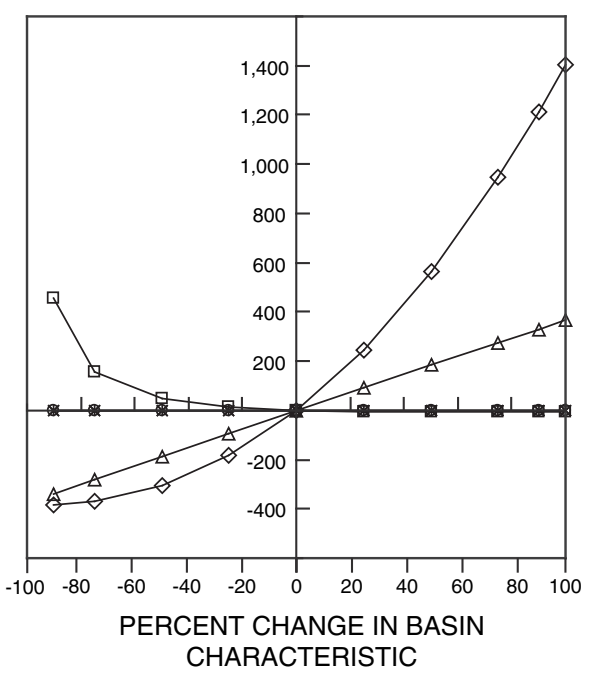

Figure 6. Sensitivity of streamflow at the 10-, 50-, and 90-percent exceedence probabilities calculated by the $0 P P 0$ method (Fennessey, 1994) to values of drainage-area characteristics for four drinking-water reservoirs in Massachusetts: $A$, Granville Reservoir, Westfield Water Department; $B$, Belmont Reservoir, Hinsdale Water Department; $C$, Hatchet Pond, Southbridge Water Department; and $D$, Millham Reservoir, Marlborough Water and Sewer Division-Department of Public Works. 
C.

Hatchet Pond (no. 20 on fig. 3) at 10-percent exceedence probability

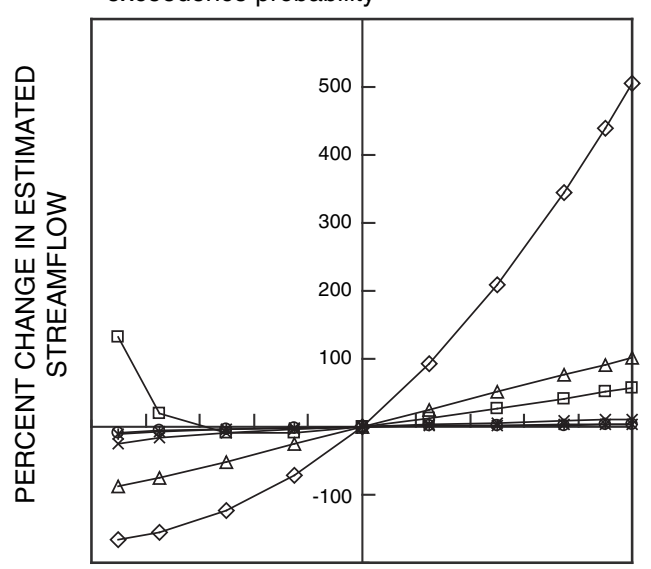

Hatchet Pond at 50-percent exceedence probability

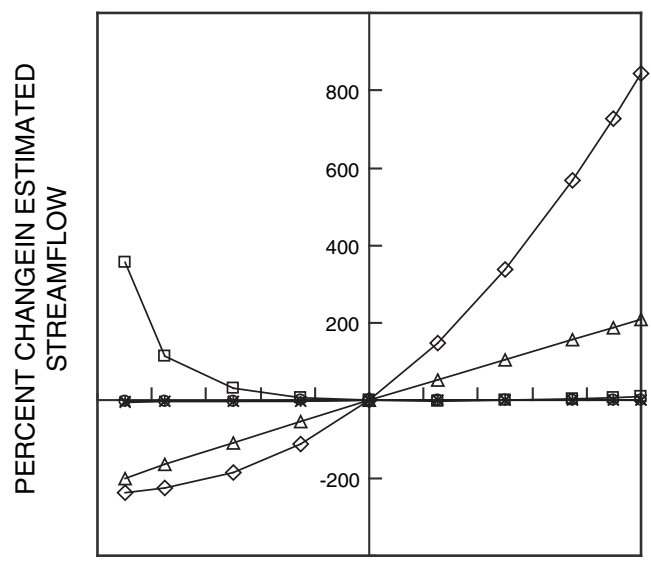

Hatchet Pond at 90-percent exceedence probability

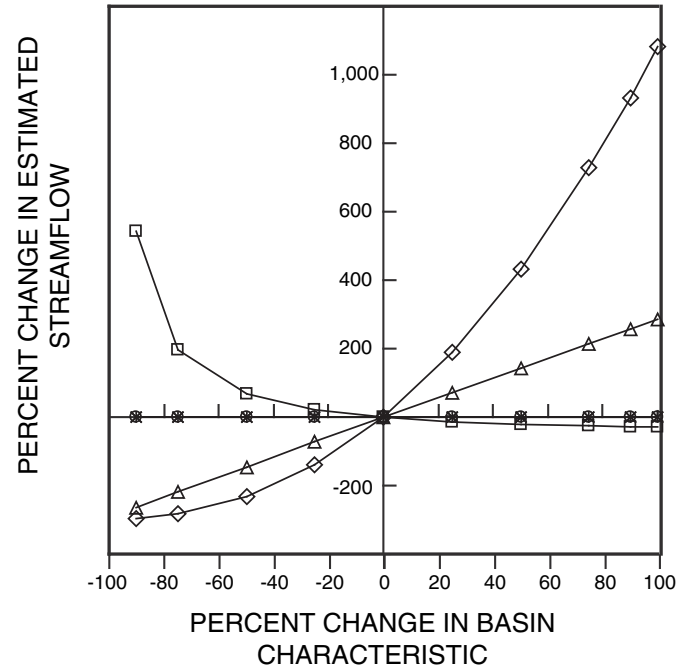

$D$.

Millham Reservoir (no. 39 on fig. 3) at 10-percent exceedence probability

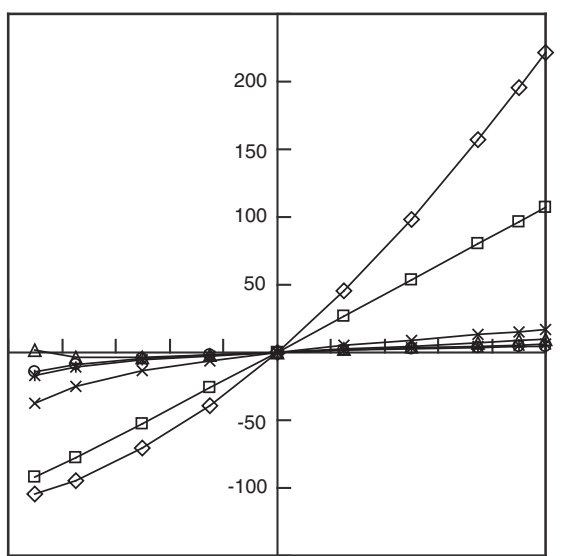

EXPLANATION

$\diamond$ PREC

E-AREA

$\triangle$ SOIL

* SNOW

*-B-ELEV

- C-SLOPE

Millham Reservoir at 50-percent

exceedence probability

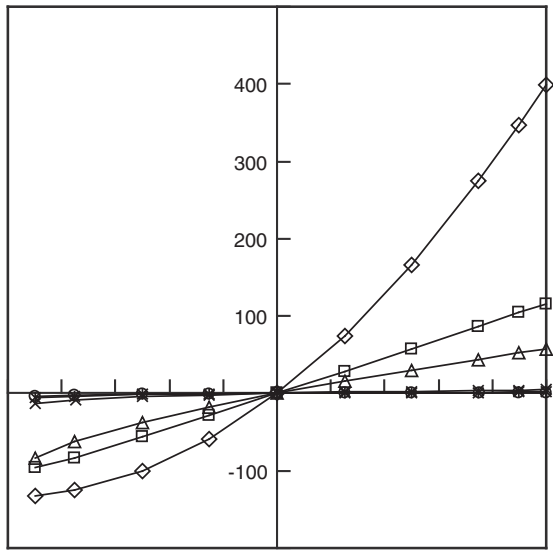

Millham Reservoir at 90-percent exceedence probability

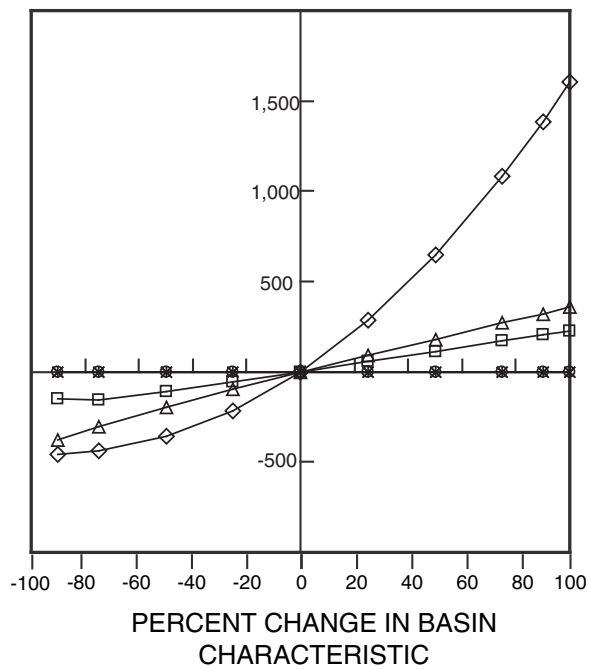

Figure 6. Sensitivity of streamflow at the 10-, 50-, and 90-percent exceedence probabilities calculated by the $0 P P 0$ method (Fennessey, 1994) to values of drainage-area characteristics for four drinking-water reservoirs in Massachusetts: $A$, Granville Reservoir, Westfield Water Department; $B$, Belmont Reservoir, Hinsdale Water Department; $C$, Hatchet Pond, Southbridge Water Department; and D, Millham Reservoir, Marlborough Water and Sewer Division-Department of Public Works.Continued 


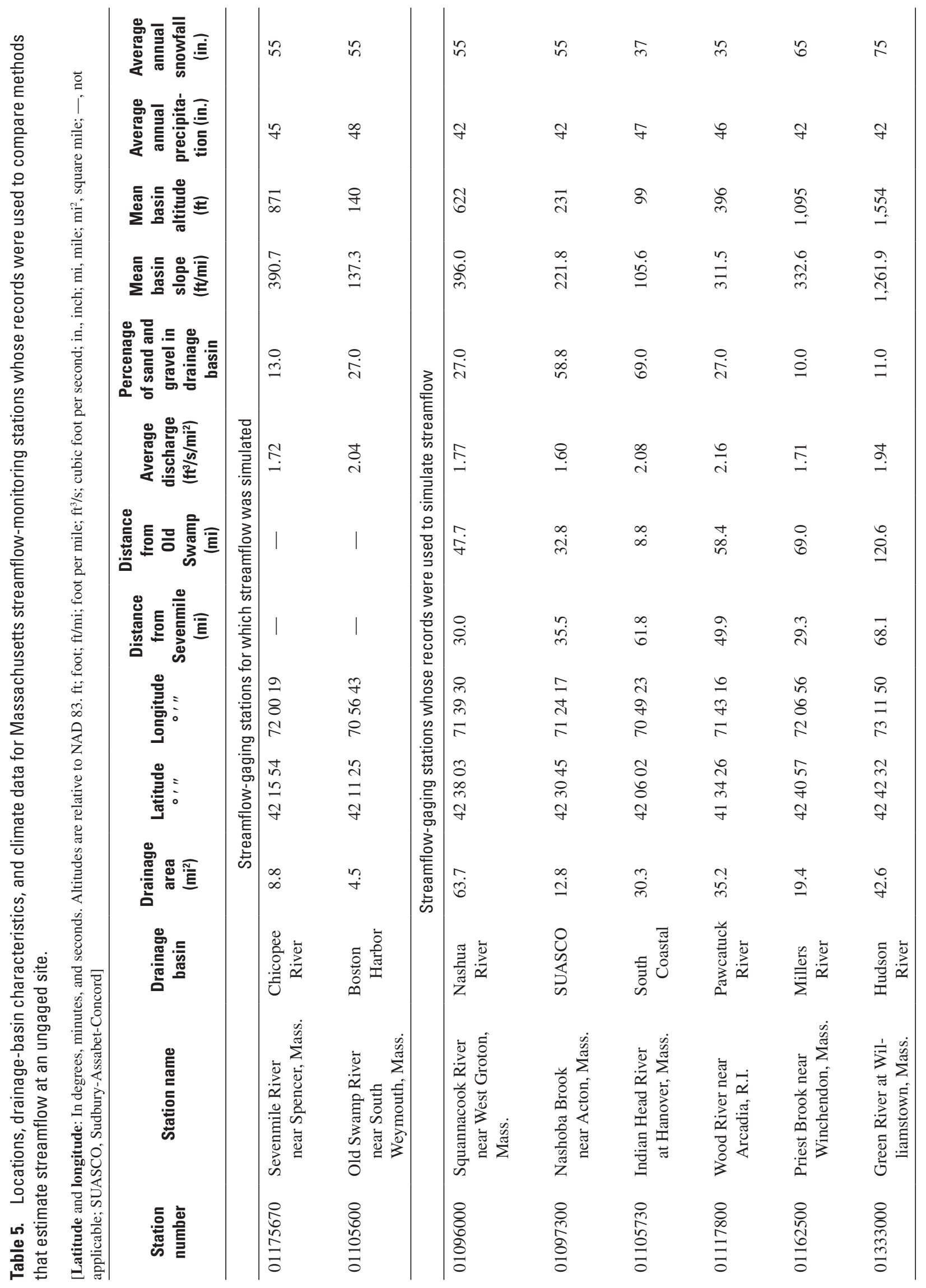


Streamflow was assumed to be unknown at Sevenmile River near Spencer, Mass. (01175670) and at Old Swamp River near South Weymouth, Mass. (01105600). These stations were selected because of their different flow and basin characteristics: drainage area (the ratio of Sevenmile's drainage area to Old Swamp's is almost 2), average discharge (the ratio is about 1.7), percent sand and gravel in the drainage basin (the ratio is about one-half), mean basin slope (the ratio is about 3 ), and mean basin elevation (the ratio is about 6 ). The six streamflow-monitoring stations whose records were used as the basis for predicting flows were 8.8 miles to 120.6 miles distant from the two stations whose flows were simulated, and differed greatly with respect to the basin characteristics that are thought to influence the QPPQ method (table 5).

Observed and predicted flow durations are shown in fig. $7 A$ for the Sevenmile River and in fig. $7 B$ for the Old Swamp River. Also shown are flow durations predicted by the USGS Streamstats program (Ries and others, 2000). The flow durations were predicted equally well by transformed records from all six reference stations. There were substantial deviations from the measured discharge values only for extreme high and low flows. Whereas this analysis indicates the QPPQ method performs well in estimating mean monthly flows used in the firm-yield analysis, estimated flows are less reliable the further they are from the median flows. This may have implications for the calculated firm yield because flows preceding the reservoir failure are expected to be at or near the extreme low-flow condition. Further work is needed to evaluate the effect of this uncertainty in the firm-yield analysis.

\section{Selection of Surface-Water Reference Stations}

The previous analysis indicated that the QPPQ method can be used to simulate streamflows at most ungaged sites in Massachusetts and that selection of a reference streamflowgaging station should be based primarily on length of record and on the extent to which the flow at the station can be considered natural. To determine the USGS streamflow-gaging stations that can be used by the QPPQ method to determine streamflow at ungaged sites in Massachusetts, stations in the USGS streamflow-monitoring network in Massachusetts and adjacent states were examined to determine which stations were least altered by dams, withdrawals, or other diversions. This analysis resulted in the selection of 26 stations whose flows could be considered the least altered as compared to flows at other Massachusetts streamflow-monitoring stations. Of these, five are in Connecticut, three are in Rhode Island, two are in New Hampshire, and the remaining stations are in Massachusetts (fig. 8 and table 6). Many of the sites have some minimal form of regulation; detailed descriptions of the amounts and types of regulation, station locations, and basin characteristics can be found in Armstrong and others (2004).

Records for 12 of the 26 stations did not include the 1960s drought-of-record, which is a requirement of the firm-yield estimation approach adopted by the MassDEP (MassDEP, 1996). The maintenance of variance extension type 1 method (MOVE.1; Hirsch, 1982) was used to extend the records of these stations by establishing relations between the existing parts of the records and records for stations that included the drought-of-record. The MOVE.1 program correlates daily discharge at a station with limited records to discharge at a station with more extensive records. Once this relation is determined, the record can be extrapolated to include the desired period of record, in this case, the 1960s drought-of-record. In this way, all 26 sets of discharge records for minimally altered streamflow-monitoring stations were extended to include the period from October 1949 through September 2002. These extended streamflow records are included in Appendix (on the CD-ROM). The 12 monitoring stations with incomplete records are listed in table 7 with the index stations used to extend the records, and the correlation coefficients between the existing records for the index and limited-record stations.

\section{Application of the QPPQ Method to Determine Firm Yield}

The QPPQ method was applied to 45 of the 46 study reservoirs to estimate monthly sreamflows to each reservoir. Lower Ashley Intake Reservoir, Pittsfield Water Department, is downstream from Ashley Lake and provides minimal storage for water prior to treatment. Consequently, streamflows to Lower Ashley Intake Reservoir were estimated as part of the larger system that included Ashley Lake. Initial application of the QPPQ method resulted in negative streamflows to nine of the reservoirs. Based on this result, an additional analysis of the QPPQ method was done to investigate when and why the negative streamflows occurred and how the QPPQ method could be adjusted to prevent negative flows.

The QPPQ method generated negative streamflows for some ungaged sites during the low-flow periods of the indexstation records. In all cases, streamflow was negative when the FDC parameter $\xi$ was negative. An analysis indicated that $\xi$ is negative when the sum of SOIL, AREA, and PREC terms in equation 4 is less than 9.97. The value of $\xi$ can be negative because of low individual values for SOIL, AREA, and PREC, or a low value for a combination of at least two of these values.

To prevent the QPPQ method from generating negative streamflows, the value of $\xi$ was set to zero if $\xi$ initially resulted in a negative value (Neil Fennessey, Associate Professor, University of Massachusetts, Dartmouth, written commun., 2004). A comparison of the QPPQ method results with and without this correction is shown in figure 9. Note that the exclusion of $\xi$, an estimate of the lowest daily streamflow at the site (Fennessey, 1994), primarily affects the low-flow periods of the streamflow record and preserves the quantity of streamflow at peak flows. As the exceedence probability decreases, the magnitude of $\xi$ decreases relative to the magnitudes of the other terms in the QPPQ method and estimated streamflow becomes insensitive to $\xi$. The QPPQ method has been revised to incorporate this correction, and it has been coded into the appendix database. 


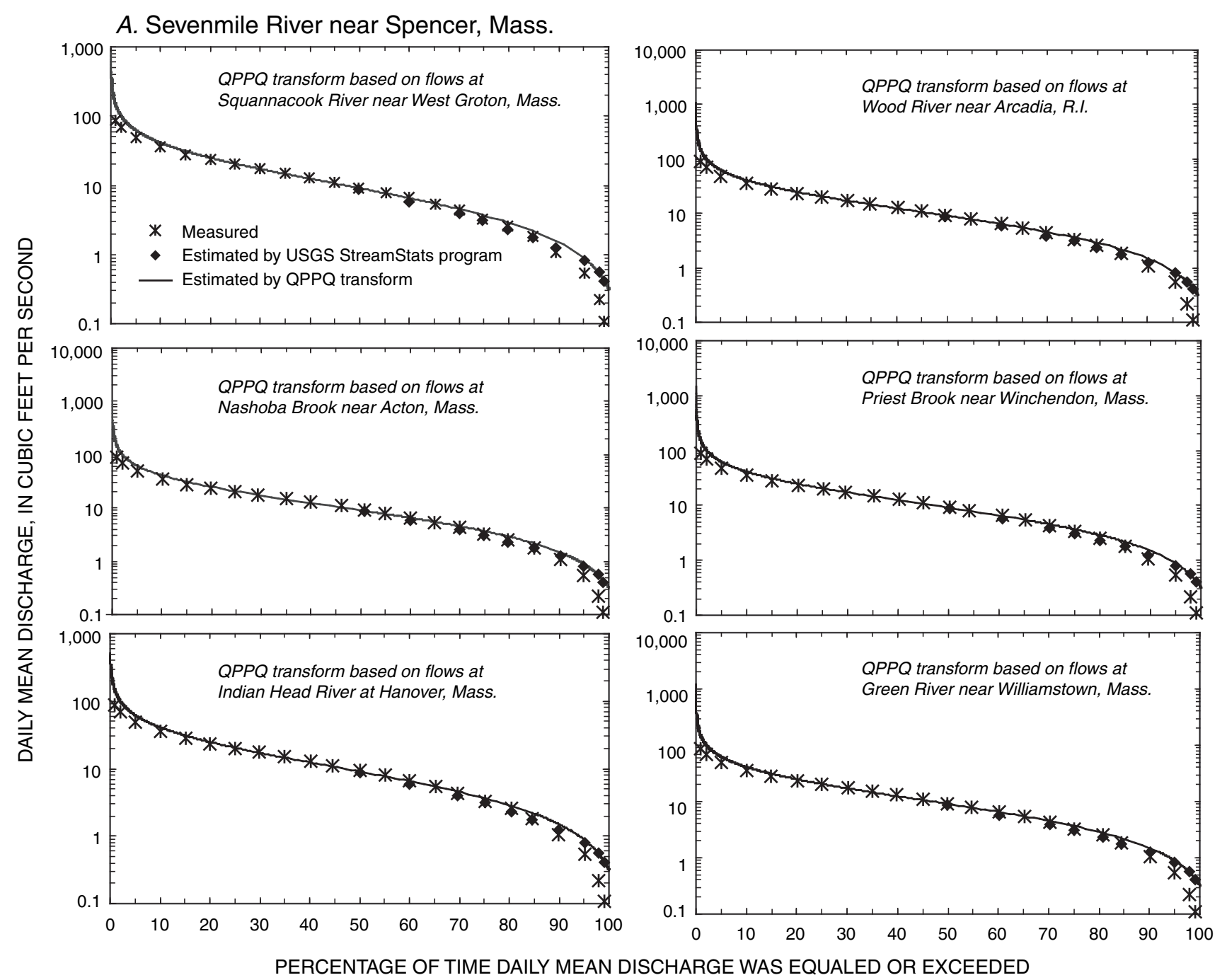

Figure 7. Flow-duration curves for $A$, Sevenmile River near Spencer, Mass. (01175670) and B, Old Swamp River near South Weymouth, Mass. (01105600) measured and estimated by applying the QPPO method (Fennessey, 1994) to records from six streamflow-gaging stations in different hydrologic settings in Massachusetts and Rhode Island.

\section{Limitations to the Application of the QPPO Method}

The regression equations in the QPPQ method were derived from a multivariate regression analysis of watershed characteristics from 166 Hydro-Climatic Data Network (HCDN) streamflow-gaging stations in the northeast and mid-Atlantic U.S. (Fennessey, 1994). The HCDN data set contains discharge measurements collected at minimally altered streamflow-gaging stations (Slack and Landwehr, 1993). Therefore, the resulting flows to the drinking-water reservoir are also considered to be minimally altered. Furthermore, the relations expressed in equations 4 through 6 were developed on the basis of sites with the following ranges of basin characteristics:
1. AREA between $1.49 \mathrm{mi}^{2}$ and $6,700 \mathrm{mi}^{2}$,

2. SOIL between $1.6 \mathrm{in}$. and $15 \mathrm{in}$.,

3. SNOW between 16.5 in. and 190.6 in.,

4. PREC between 31.0 in. and 63.0 in.,

5. C-SLOPE between $2.71 \mathrm{ft} / \mathrm{mi}$ and $326 \mathrm{ft} / \mathrm{mi}$, and

6. B-ELEV between $109 \mathrm{ft}$ and 2,800 ft.

Values of SOIL, SNOW, PREC and B-ELEV for the 46 study reservoirs were within the ranges used to develop the regression equations (table 4). The value of C-SLOPE was outside of the range for 4 study reservoirs, the value of AREA was outside of the range for 16 study reservoirs, and 5 study 
B. Old Swamp River near South Weymouth, Mass.
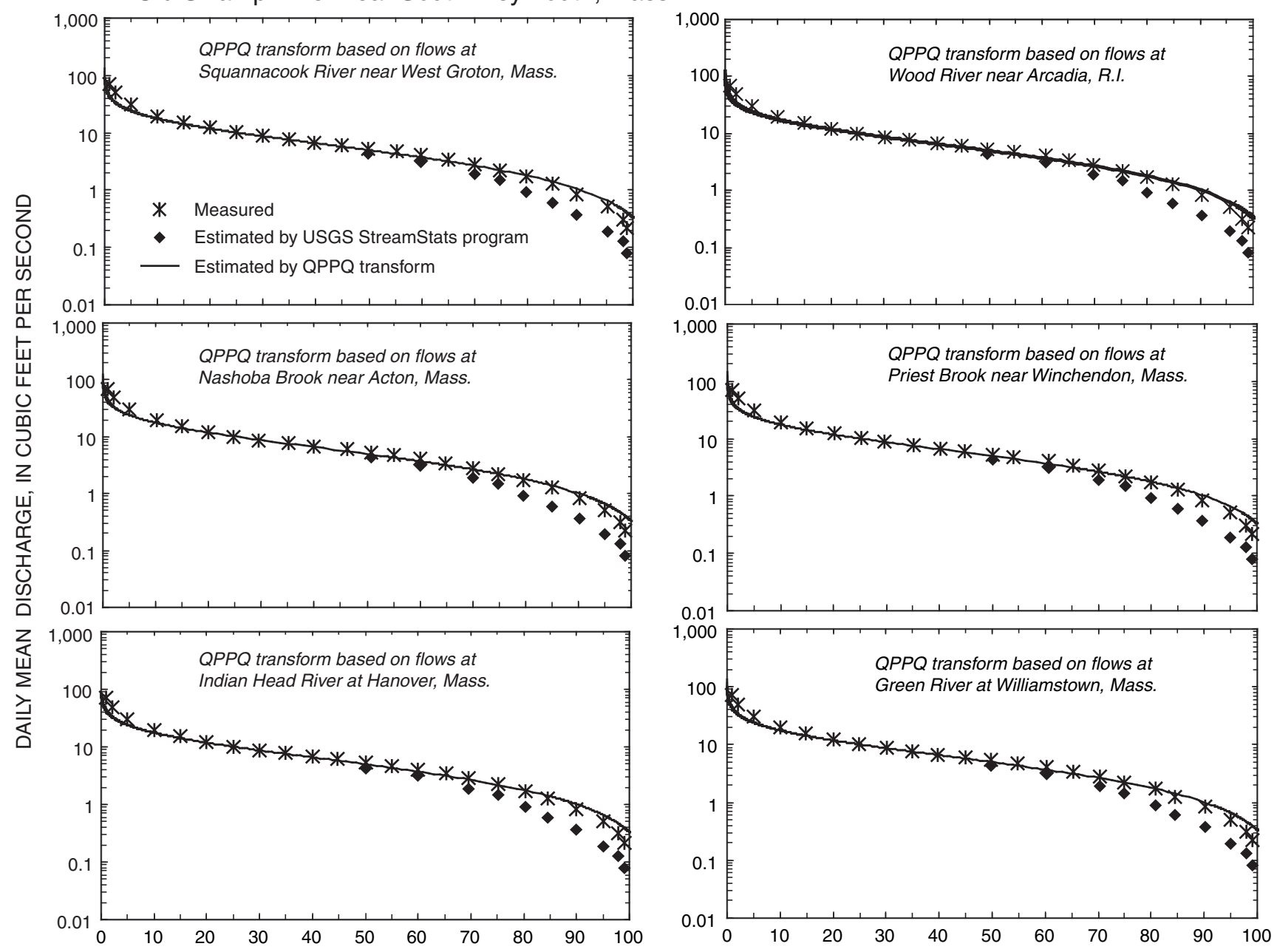

PERCENTAGE OF TIME DAILY MEAN DISCHARGE WAS EQUALED OR EXCEEDED

Figure 7. Flow-duration curves for $A$, Sevenmile River near Spencer, Mass. (01175670) and B, Old Swamp River near South Weymouth, Mass. (01105600) measured and estimated by applying the QPPQ method (Fennessey, 1994) to records from six streamflow-gaging stations in differing hydrologic settings in Massachusetts and Rhode Island.-Continued

reservoirs had C-SLOPE and AREA values outside of their respective ranges (table 4). The uncertainty in streamflow estimates will increase if one or more of the basin characteristics fall outside of the ranges used to develop equations 4-6; however, the difference between observed and predicted FDCs for Sevenmile River, which has a C-SLOPE value of 390.7 $\mathrm{ft} / \mathrm{mi}$ (table 5), did not substantially differ from the difference between observed and predicted FDCs for Old Swamp River, whose basin-characteristics values are within the ranges used to develop equations 4-6 (fig. 7).

\section{Precipitation and Streamflow Records}

The MassDEP (1996) guidance document recommends computing the firm yield of a reservoir by first using the historical record of precipitation and streamflow. If the reservoir does not refill for 15 percent of the years when the reservoir is operating at the firm yield, concurrent historical records of streamflow (simulated by the QPPQ method) and precipitation are sampled in 2-year blocks 500 times to provide a 1,000year record from which to evaluate the firm yield. Because climate and streamflow data have been collected for at most 100 years, the intended purpose of this sampling procedureknown as bootstrapping-is to provide a means to determine the firm yield from a much longer record of climate and hydrologic conditions (MassDEP, 1996); however, because the use of the bootstrap in firm-yield analysis is not a widelyaccepted practice, the application of the bootstrap to reservoirs in Massachusetts had not been evaluated prior to this study.

To evaluate if a synthetic record of streamflow generated from sampling 2-year blocks of the historical record is statistically equivalent to the historical record of streamflow, 


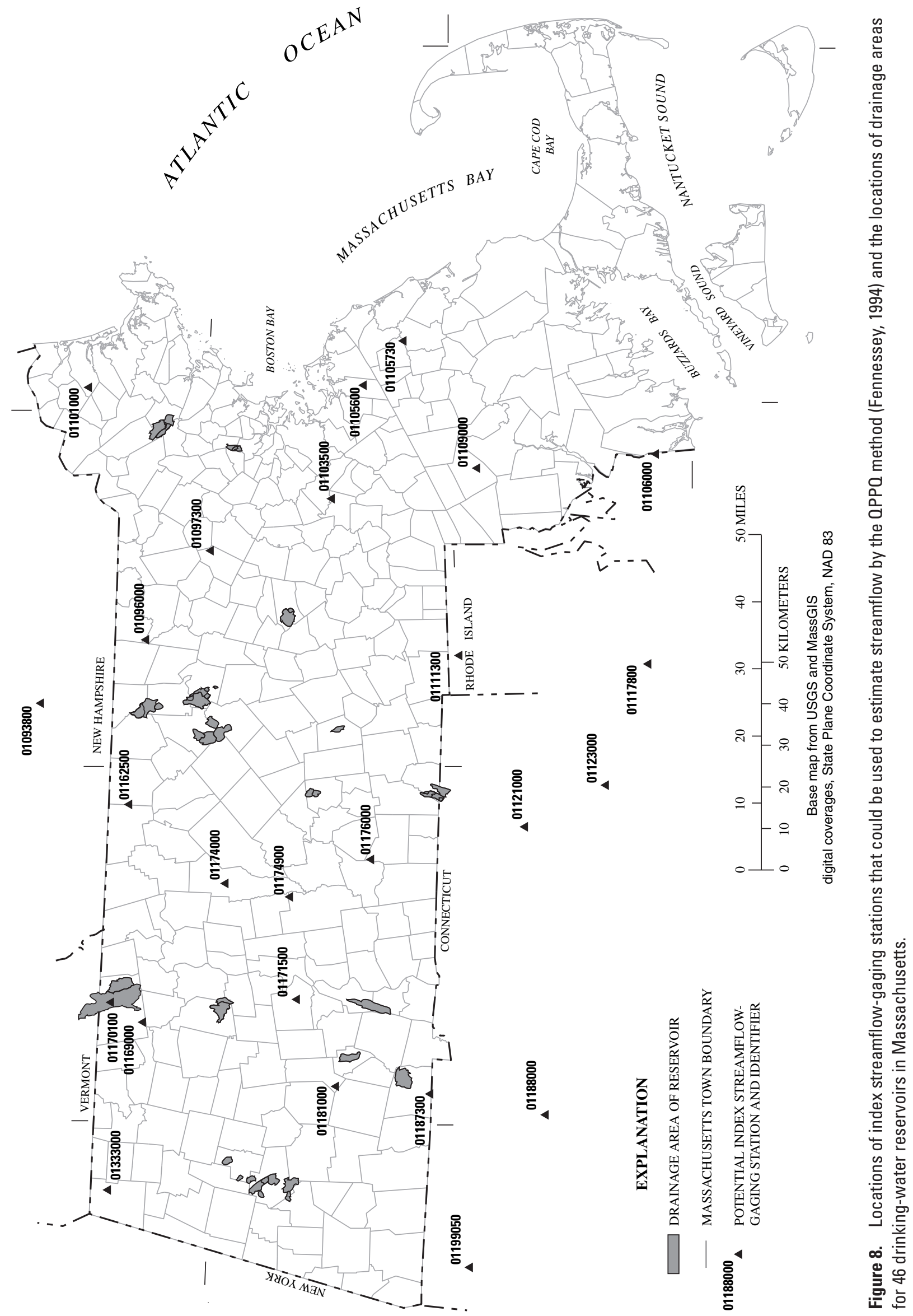


Table 6. Identifiers, names, drainage areas, and records for 26 streamflow-monitoring stations that could be used to estimate surface-water flows to reservoirs in Massachusetts.

[USGS, U.S. Geological Survey; $\mathrm{mi}^{2}$, square mile]

\begin{tabular}{|c|c|c|c|}
\hline $\begin{array}{l}\text { USGS } \\
\text { station } \\
\text { identifier }\end{array}$ & USGS station name & $\begin{array}{c}\text { Drainage } \\
\text { area } \\
\left(\mathrm{mi}^{2}\right)\end{array}$ & Period of record \\
\hline 01073000 & Oyster River near Durham, N.H. & 12.1 & October 1934-September 2002 \\
\hline 01093800 & Stony Brook near Temple, N.H. & 3.60 & May 1963-September 2002 \\
\hline 01096000 & Squannacook River near West Groton, Mass. & 63.7 & October 1949-September 2002 \\
\hline 01097300 & Nashoba Brook near Acton, Mass. & 12.8 & July 1963-September 2002 \\
\hline 01101000 & Parker River at Byfield, Mass. & 21.3 & October 1945-September 2002 \\
\hline 01103500 & Charles River at Dover, Mass. & 183 & October 1937-September 2002 \\
\hline 01105600 & Old Swamp River near South Weymouth, Mass. & 4.29 & May 1966-September 2002 \\
\hline 01105730 & Indian Head River at Hanover, Mass. & 30.3 & July 1966-September 2002 \\
\hline 01106000 & Adamsville Brook at Adamsville, R.I. & 7.91 & October 1940-September 1978 \\
\hline 01109000 & Wading River near Norton, Mass. & 43.3 & July 1925-September 2002 \\
\hline 01111300 & Nipmuc River near Harrisville, R.I. & 16.0 & $\begin{array}{l}\text { March 1964-September 1991, } \\
\text { October 1993-September } 2002\end{array}$ \\
\hline 01117800 & Wood River near Arcadia, R.I. & 35.2 & January 1964-September 2002 \\
\hline 01121000 & Mount Hope River near Warrenville, Conn. & 28.6 & October 1940-September 2002 \\
\hline 01123000 & Little River near Hanover, Conn. & 30.0 & October 1951-September 2002 \\
\hline 01162500 & Priest Brook near Winchendon, Mass. & 19.4 & July 1918-September 2002 \\
\hline 01169000 & North River at Shattuckville, Mass. & 89.0 & December 1939-September 2002 \\
\hline 01170100 & Green River near Colrain, Mass. & 41.4 & October 1967-September 2002 \\
\hline 01171500 & Mill River at Northhampton, Mass. & 54.0 & November 1938-September 2002 \\
\hline 01174000 & Hop Brook near New Salem, Mass. & 3.39 & November 1947-September 1982 \\
\hline 01174900 & Caldwell Creek near Belchertown, Mass. & 2.81 & July 1961-September 1997 \\
\hline 01176000 & Quaboag River at West Brimfield, Mass. & 150 & August 1912-September 2002 \\
\hline 01181000 & West Branch Westfield River at Huntington, Mass. & 93.7 & September 1935-September 2002 \\
\hline 01187300 & Hubbard River near West Hartland, Conn. & 19.9 & October 1938-September 2002 \\
\hline 01188000 & Burlington Brook near Burlington, Conn. & 4.10 & October 1931-September 2002 \\
\hline 01199050 & Salmon Creek at Lime Rock, Conn. & 29.4 & October 1961-September 2002 \\
\hline 01333000 & Green River at Williamstown, Mass. & 42.6 & October 1949-September 2002 \\
\hline
\end{tabular}


Table 7. Streamflow-monitoring stations used as reference stations to estimate reservoir inflows, portions of streamflow records estimated for the stations, index stations used in the estimation, and correlation coefficients between log-transformed flow records for index and target stations.

[USGS, U.S. Geological Survey]

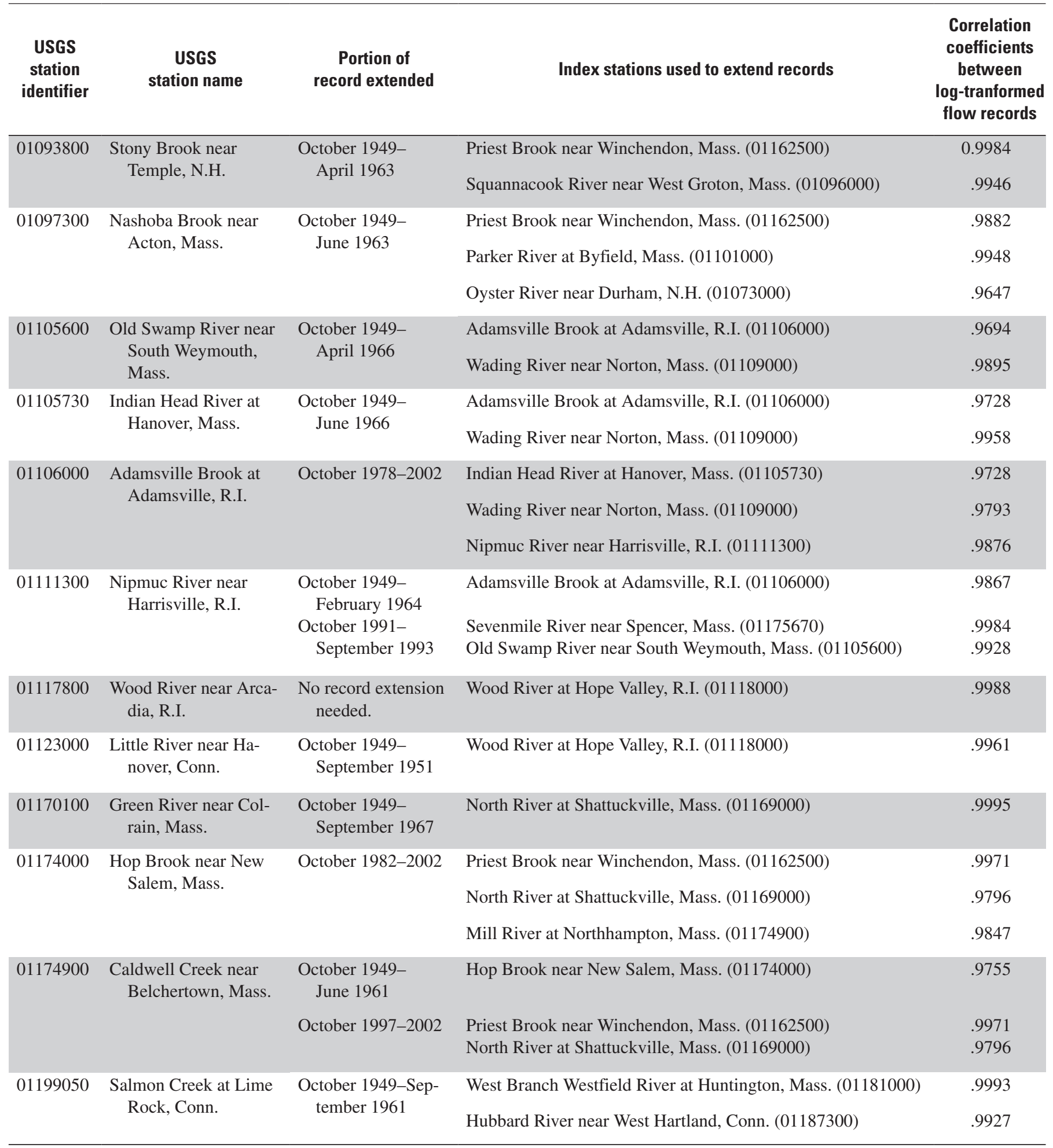




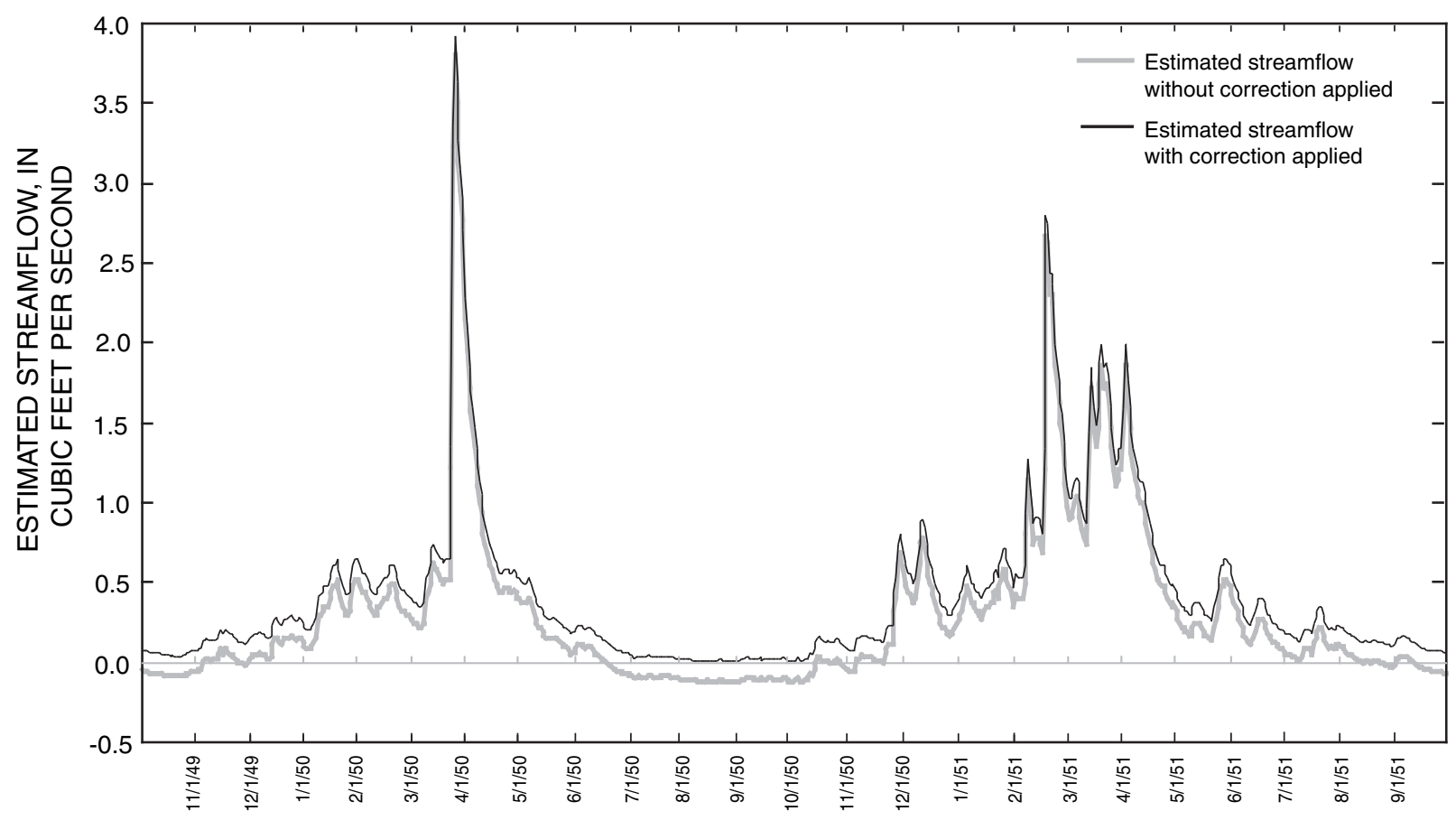

Figure 9. Comparison of estimated streamflows into Scott Reservoir from October 1949 through September 1951, Fitchburg Water Department, Massachusetts. Streamflow was estimated by using the QPPO method (Fennessey, 1994).

the serial correlation in the historical record is compared to the serial correlation of 2-year blocks of streamflow. Firm yields for the study reservoirs determined from the historical record, which contained the 1960s drought, were compared to 30 firm yields determined from 30 synthetic records for 4 drinkingwater reservoirs in Massachusetts.

\section{Comparison of Serial Correlation in the Historical and Synthetic Records}

The bootstrap-sampling method is based on the assumption that the observed data points are independent of each other. Randomly sampling the original data set destroys any relationship between the data points, particularly if the value of one data point depends on another. The assumption of independence complicates the application of the bootstrap to streamflow because observations of streamflow over time are not independent of one another.

To preserve the serial correlation in the observed streamflow, the historical record is divided into large enough time blocks so that the blocks themselves are essentially independent. The effective serial correlation in the bootstrapped record can be compared to the serial correlation in the observed streamflow record to determine an appropriate time-block length. Vogel and Shallcross (1996) present the following equation to estimate what fraction of the serial correlation in the observed streamflow is preserved in a bootstrapped synthetic record. The equation is based on the assumption that the streamflow is characterized by a first-order autoregressive $(\mathrm{AR}(1))$ model:

$$
\rho_{\text {effective }}=\frac{\lambda-1}{\lambda} \rho
$$

where

$$
\begin{aligned}
\rho_{\text {effective }}=\quad \begin{array}{l}
\text { average effective serial correlation of the } \\
\text { bootstrapped record },
\end{array} \\
\lambda=\begin{array}{l}
\text { block length }=[(\text { record length }) /(\text { number } \\
\text { of blocks to sample })], \text { and }
\end{array} \\
\rho=\begin{array}{l}
\text { serial correlation in the observed } \\
\text { streamflow. }
\end{array}
\end{aligned}
$$

The MassDEP (1996) guidance document is based on the assumption that blocks of 2 years are statistically independent from one another; however, equation 8 shows that dividing the historical record into 2-year blocks preserves half of the serial correlation in the original streamflow record. As $\lambda$ increases, $\rho_{\text {effective }}$ approaches $\rho$ (fig. 10); for values of $\lambda$ equal to or greater than 5,80 percent or more of the serial correlation in the original streamflow record is preserved. Although the structure of monthly streamflows is not typically represented by an $\mathrm{AR}(1)$ process, Vogel and others (1998) have shown that the structure of historical streamflow sequences is indistinguishable from the structure represented by more complicated stochastic models. 


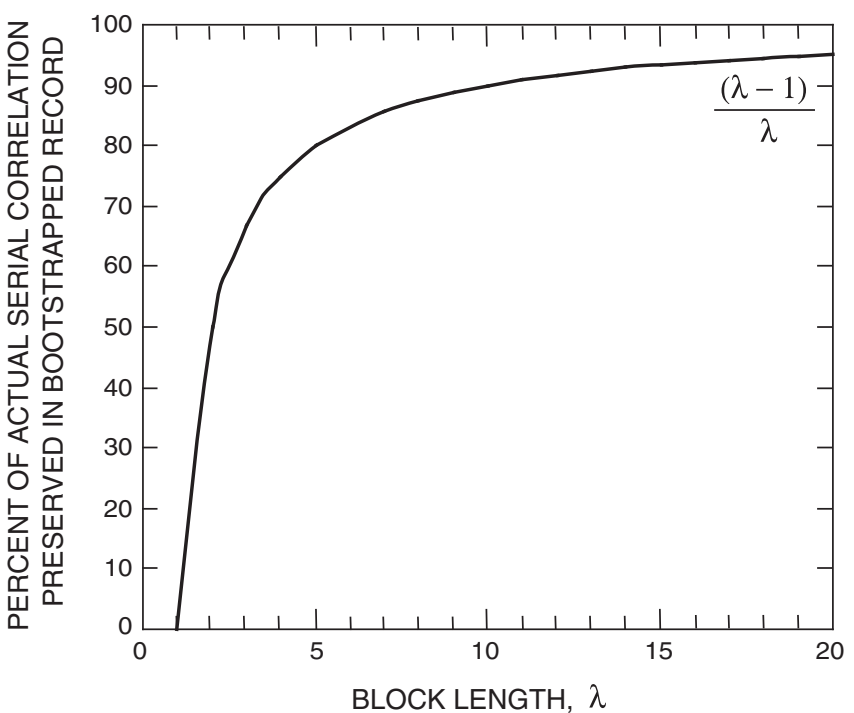

Figure 10. Relationship between the block length used to bootstrap a synthetic record of streamflow and the percentage of serial correlation in the observed streamflow that is preserved in the synthetic record (Vogel and Shallcross, 1996).

As $\lambda$ increases, the number of blocks to sample decreases. Therefore, the larger the block length, the more likely it is that the serial correlation in the original streamflow will be preserved in the synthetic record; however, the number of samples from which to construct a synthetic record will be smaller (Vogel and Shallcross, 1996). The lengths of historical, concurrent streamflow and precipitation records for the study reservoirs ranged from 33 to 43 years, which provided 16 to 212 -year blocks from which to construct the synthetic record. If the block length were increased from 2 years to 5 years, the synthetic record would be constructed from randomly sampling 6 to 8 blocks 200 times. Moreover, because fewer than half of the reservoirs in Massachusetts have a period of drawdown that exceeds 2 years, larger block lengths increase the possibility that the reservoir will completely refill within the block length; thus, the bootstrap cannot generate alternate sequences of reservoir drawdown across blocks under these conditions.

\section{Comparison of Firm Yields Determined from the Historical and Synthetic Records}

The bootstrap, as implemented by the MassDEP (1996) guidance document, randomly samples blocks of the historical streamflow and precipitation record; therefore, the value of firm yield may differ from one simulation to the next because the order in which the blocks are sampled will differ. To examine the differences between firm yields determined from the historical record and firm yields determined from a synthetic record, firm yields for four reservoirs were determined by the historical record and compared to 30 firm yields determined from 30 synthetic records for each respective reservoir. All firm yields were determined from QPPQ-estimated streamflow values and included precipitation and evaporation in the reservoir water-balance equation. The four reservoirs selected for this experiment were: Bearhole Reservoir, Cleveland Reservoir, Fall Brook Reservoir, and Upper (Leahey) Reservoir. To determine if the difference in firm yield between the historical record and synthetic records was related to some refill criterion, the trace of reservoir storage versus time was plotted for the study reservoirs while the respective reservoirs were operating at the firm yield determined by the historical record. The number of times the reservoir refilled within each 2-year block was determined. The selected reservoirs were chosen to represent a range of refill fractions (fig. 11). No rationale for the 15-percent refill criterion was provided in the original MassDEP (1996) guidance document and, because 2-year blocks - not 1-year blocks - are used in the construction of the synthetic record, the capability of the bootstrap to generate alternative drawdown conditions for the reservoir lies in the behavior of the reservoir within each 2-year block.

The repeated calculation of firm yield by a synthetic record resulted in values of firm yield higher and lower than the firm-yield value determined by the historical record for two of the four selected reservoirs (fig. 11). The average difference for the four reservoirs between the maximum and minimum values of 30 firm yields obtained from the 30 synthetic records was 16 percent. The difference was as large as 30 percent for Upper (Leahey) Reservoir (fig. 11). For this reservoir, the use of a synthetic record to determine firm yield resulted in as much as a 30-percent difference between firmyield values from one simulation to the next. For the case of Cleveland Reservoir, the firm-yield values obtained from 30 synthetic records were also variable; however, the firm-yield values determined from 30 synthetic records were all lower than the firm yield determined from the historical record. It is possible that this observation is a result of sampling; firmyield values determined from other synthetic records could result in firm-yield values higher than the firm yield determined from the historical record.

Bearhole Reservoir did not show any variation between the firm yield determined by the historical record and the firm yields determined from 30 synthetic records. When operating at the firm yield determined by the historical record, Bearhole Reservoir completely refills every 2 years even within the 2-year block that contains the critical month in which all available storage was depleted. Therefore, neither the sequencing of the blocks nor length of the synthetic record will result in different firm-yield values because the reservoir always starts full every 2 years. The only difference in firm 
A.

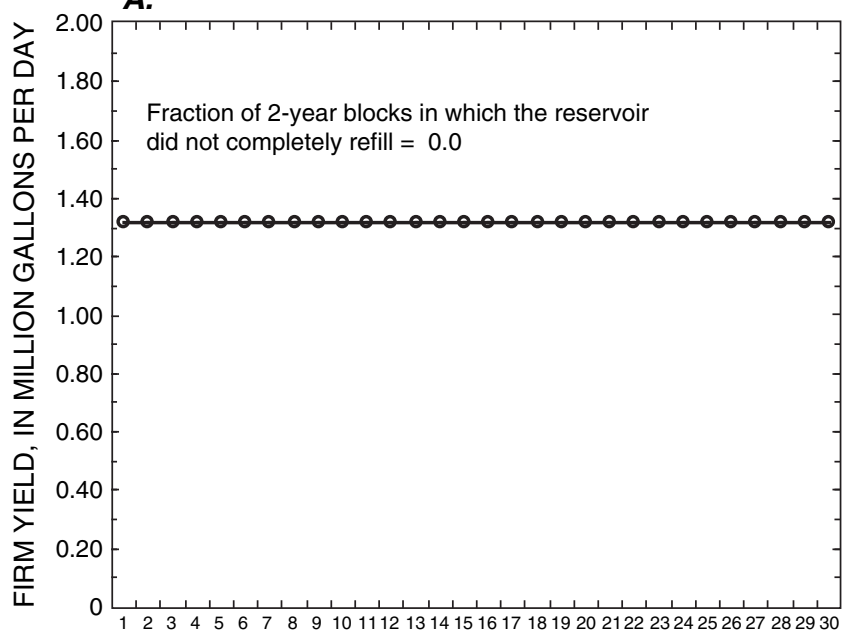

C.

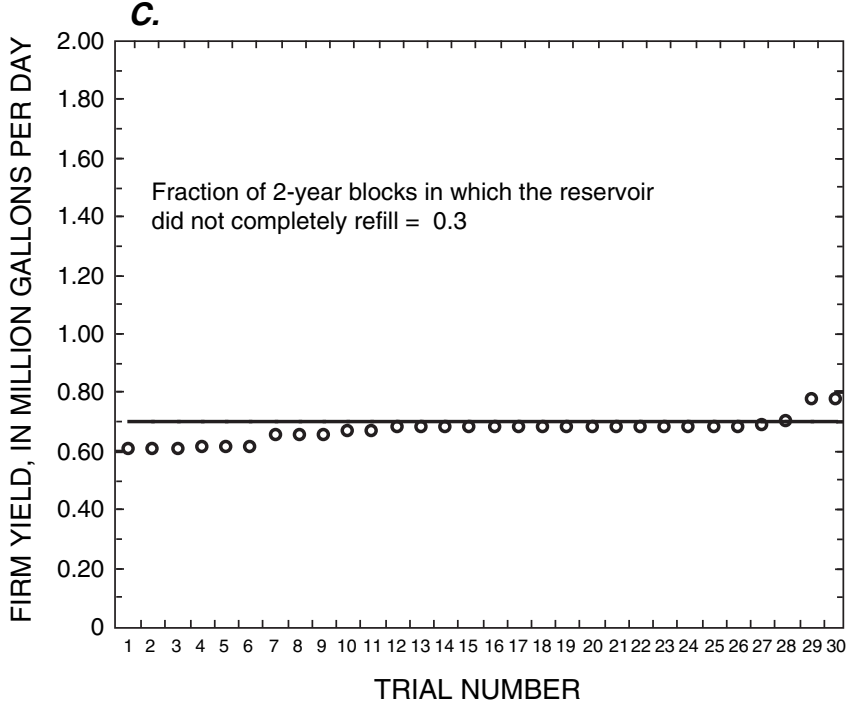

B.

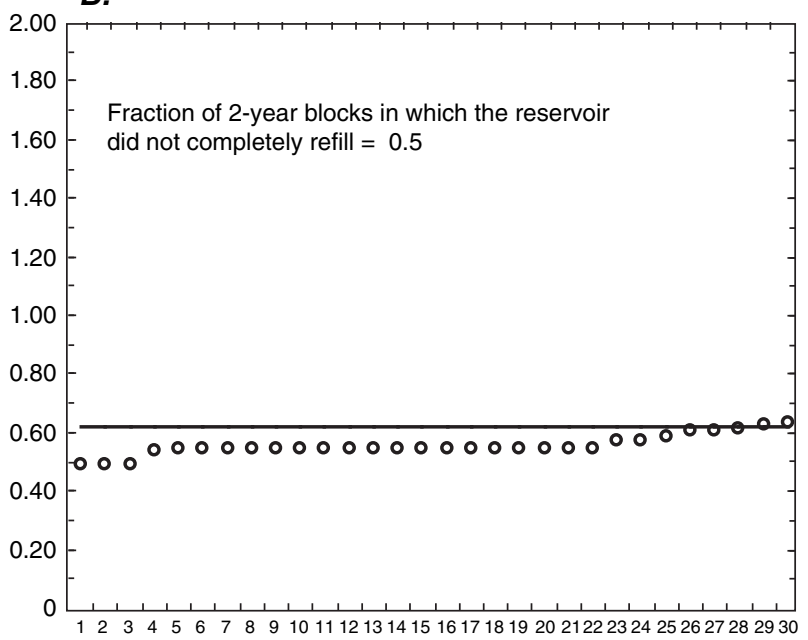

D.

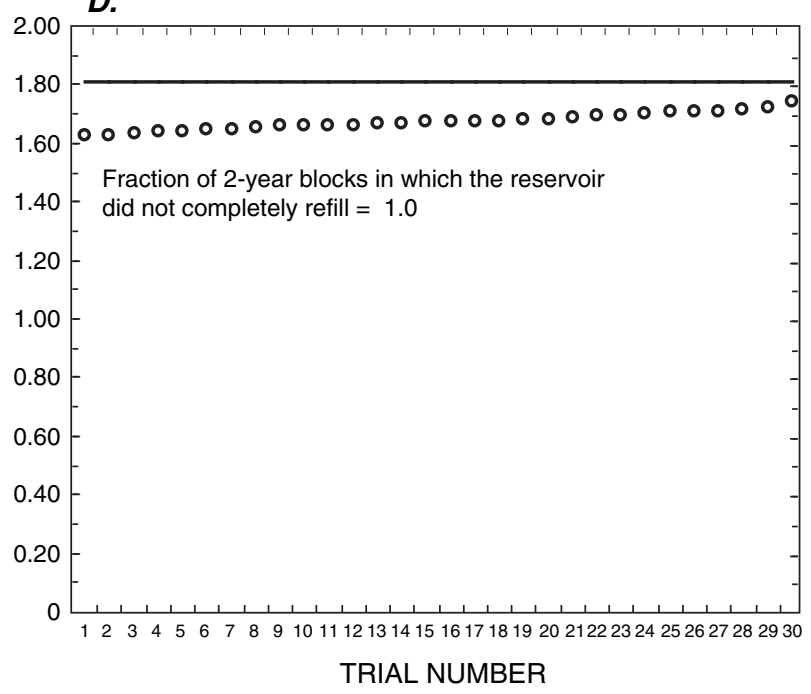

\section{EXPLANATION}

\section{- FIRM YIELD DETERMINED FROM SYNTHETIC RECORDS \\ - FIRM YIELD DETERMINED FROM HISTORICAL RECORD}

Figure 11. Comparison of firm yields determined from the historical record and 30 synthetic records constructed by bootstrapping 2-year blocks of the historical record for $A$, Bearhole Reservoir, West Springfield Water Department, shown as reservoir 16 on figure 3; $B$, Upper (Leahey) Reservoir, Lee Water Department, shown as reservoir 1 on figure 3; $C$, Fall Brook Reservoir, Leominster Department of Public Works-Water Division, shown as reservoir 36 on figure 3; and $D$, Cleveland Reservoir, Pittsfield Water Department, shown as reservoir 6 on figure 3.

yield that could result from the use of a synthetic record would occur if the 2-year block containing the critical month of failure was not sampled.

Whereas the synthetic record has the potential to generate streamflow and precipitation sequences that result in lower firm yields than the firm yield determined from the historical record, the synthetic record also has the potential to generate records of precipitation and streamflow that do not reflect the worst historical drought that has occurred in Massachusetts. Furthermore, for reservoirs that do not experience periods of drawdown greater than the block length, the bootstrap does not offer any additional information about the firm yield of a reservoir than the historical record does. 
Table 8. Firm-yield estimates determined by the historical record of streamflow and precipitation for 14 single-reservoir systems in Massachusetts.

[Reservoir ID: identifier from figure 3. Mgal/d, million gallons per day]

\begin{tabular}{llcc}
\hline \multicolumn{1}{c}{ Water supplier } & \multicolumn{1}{c}{ Reservoir name } & Reservoir ID & Reservoir firm yield, in Mgal/d \\
\hline Fitchburg Water Department & Wachusett Reservoir & 28 & 1.07 \\
Greenfield Water Department & Leyden Glen Reservoir & 11 & 1.20 \\
& Green River & 10 & 1.03 \\
Hinsdale Water Department & Belmont Reservoir & 9 & 0.34 \\
Lee Water Department & Upper (Leahey) Reservoir & 1 & 0.62 \\
& Schoolhouse Reservoir & 2 & 1.55 \\
Leicester (Cherry Valley and Rochdale Water) & Henshaw Pond & 24 & 0.70 \\
Leominster DPW-Water Division & Fall Brook Reservoir & 36 & 0.70 \\
Pittsfield Water Department & Ashley Lake & 4 & 0.63 \\
& Cleveland Reservoir & 6 & 1.81 \\
Westfield Water Department & Upper Sackett Reservoir & 5 & 0.68 \\
West Springfield Water Department & Granville Reservoir & 15 & 3.33 \\
\hline
\end{tabular}

\section{Applications of the Firm-Yield Estimator Model}

Because a synthetic record generated from randomly sampled 2-year blocks of the historical record offers no better estimate of firm yield than does the historical record, and because the assumption that the synthetic traces of streamflow are statistically equivalent to the historical record is not valid, firm yields were calculated by using the historical record of streamflow and precipitation. This record always contained the drought of the 1960s. Streamflow was determined by the QPPQ method, and monthly evaporation was estimated by the regression equations developed by Fennessey and Vogel (1996). The length of the historical record used in the firm-yield calculations varied between 33 and 43 years. The month in which all available storage in the reservoir was depleted always occurred during the drought of the 1960s, which is considered to be the worst drought on record in Massachusetts. A correction factor developed by Fennessey (1995) was applied to each firm-yield estimate to correct for the error introduced by using a monthly time step instead of a daily time step; however, the correction factor is derived from a regression relation and its applicability may be limited.

Lower Ashley Intake Reservoir, Pittsfield Water Department, is used to hold water withdrawn from Ashley Lake until treatment. Therefore, it was not appropriate to determine a firm yield for Lower Ashley Intake Reservoir; however, the contributing drainage area to Lower Ashley
Intake Reservoir was considered when estimating the firm yield of Ashley Lake. For these reasons, firm-yield estimates were determined for 45 of the 46 study reservoirs, excluding the Lower Ashley Intake Reservoir. Of those 45 reservoirs, 14 were single-reservoir systems and 31 were within one of 11 multiple-reservoir systems. Current water-use data indicate that, on average, 20 of the 25 reservoir systems in the study were operating below their estimated firm yield; during months with peak demands, withdrawals exceeded the firm yield for 8 reservoir systems.

\section{Application of the Firm-Yield Estimator Model to a Single-Reservoir System}

A single-reservoir system contains a reservoir that does not give or receive water from another reservoir. Therefore, the available storage in the reservoir in a given month is dependent only upon the inflows to and outflows from the reservoir, as shown in equation 2 (p. 4); sources of water to the reservoir do not include water received from another reservoir in the system. Firm yields for the 14 single-reservoir systems are shown in table 8 . The procedure that was used to compute the firm yields of these single-reservoir systems was:

1. Known inflow and outflow values for the reservoir water-balance equation were assembled from the historical record;

2. The water-balance equation for the reservoir was solved with $Q_{y}$ initially set to 0 ; 

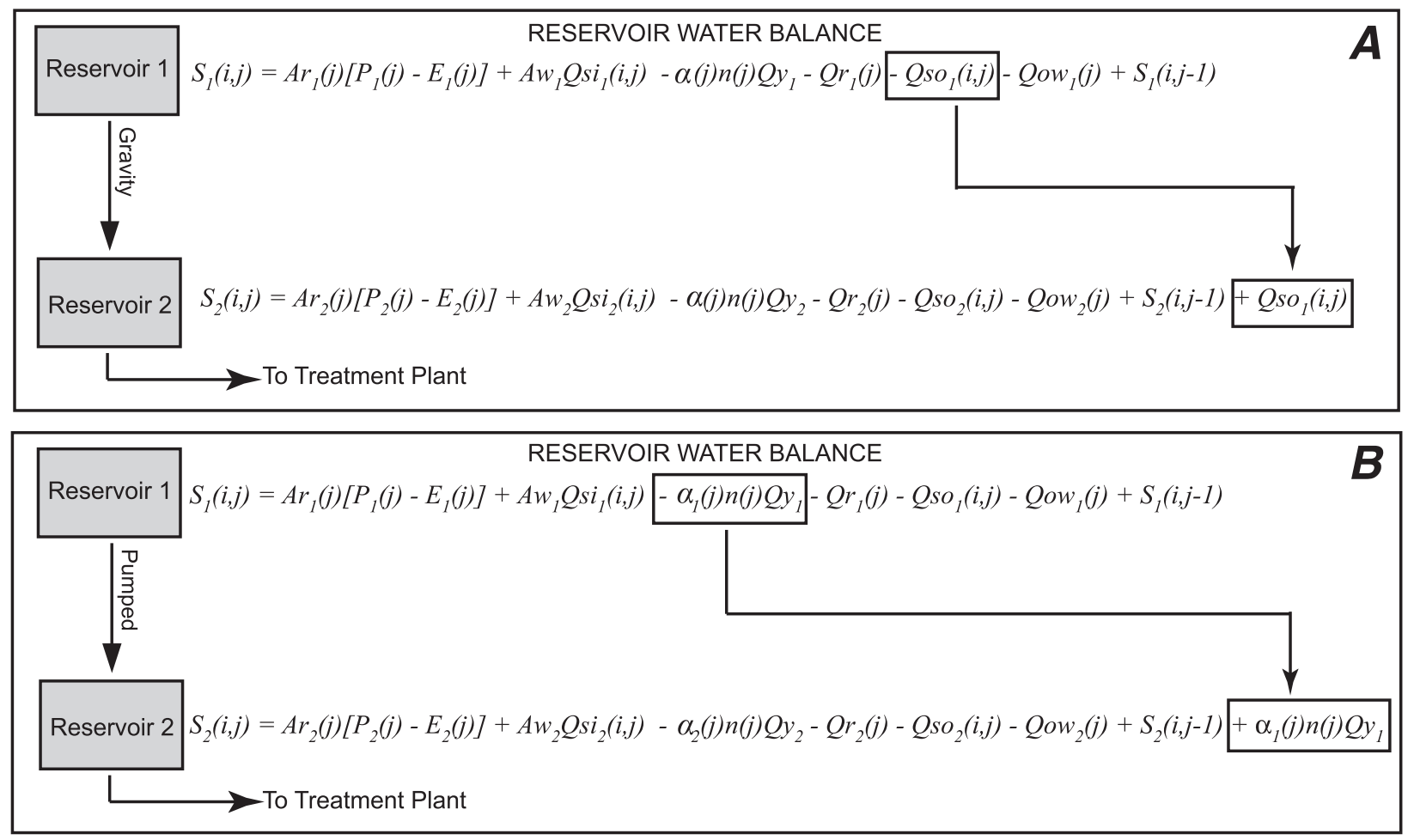

\section{EXPLANATION}
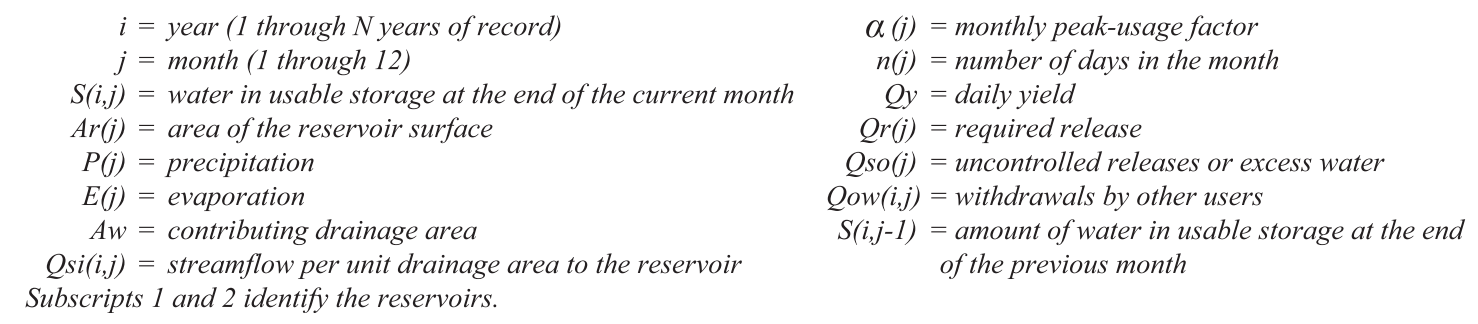

Figure 12. Water balances for a system of reservoirs in which $A$, water is released from reservoir 1 in an uncontrolled manner and is transported by gravity to reservoir 2; and $B$, water is pumped from reservoir 1 to reservoir 2 .

3. The yield $Q_{y}$ was incrementally increased until the reservoir's usable storage was completely depleted for no more than one month of the synthetic record; and

4. The correction factor that accounts for the model time step was applied to the final value of $Q_{y}$, which resulted in the firm-yield value for the reservoir.

\section{Application of the Firm-Yield Estimator Model to Multiple-Reservoir Systems}

Of the 45 reservoirs included in this study, 31 belonged to one of 11 reservoir systems. The algorithm for the estimation of the firm yield for multiple-reservoir systems depends on the system-specific connections and, of the 11 reservoir systems, none were configured the same. For this reason, application of the Firm Yield Estimator model to actual reservoir systems led to deviations from the MassDEP (1996) estimation procedures. The following section explains how the 11 study reservoir systems were simulated, and how the estimation procedures differed from the procedures outlined by the MassDEP (1996) guidance document.

For the reservoirs included in this study, water is transferred from one reservoir to another in two ways: (1) water is released from one reservoir and then transported by gravity to another reservoir, or (2) water is pumped from one reservoir into another (fig. 12). How water is transferred from one reservoir to another, the application of the peak-usage factors, and the capacity of the connection between the reservoirs to transport water (because of such factors as pipe-wall friction, for example) require additional consideration when estimating the firm yield as compared to single-reservoir systems. 
Furthermore, because the water balance of a reservoir receiving water depends on the water balance of the reservoir giving the water, the same period of the historical record was applied to all reservoirs in the system.

\section{Reservoirs Connected by Gravity}

The estimation of the firm yield for a reservoir that receives additional water from uncontrolled releases through transport by gravity depends on the water balance of the reservoir releasing the water to this reservoir. The water-balance equation for such a reservoir includes an additional term for uncontrolled releases $Q s o_{l}(j)$ where the subscript 1 identifies this reservoir as the reservoir releasing the water (fig. 12A). The value of $Q s o_{l}(j)$ must be determined first before the firm yield can be estimated for reservoir 2, because $Q s o_{l}(j)$ is an inflow to reservoir 2 . To estimate the firm yields of reservoirs 1 and 2 successively, the following steps were used:

1. Known inflow and outflow values for the water-balance equation for reservoir 1 were assembled from the historical record;

2. The water-balance equation for reservoir 1 was solved with the yield $Q y_{1}$ initially set to 0 (fig. 12A);

3. The value of the uncontrolled release $Q s o_{1}(j)$ in a given month was determined after the water-balance equation was solved by comparing the value for $S_{1}$ to reservoir 1 's maximum usable storage. If $S_{1}$ was greater than the maximum storage, the excess was assumed to represent the total uncontrolled release from reservoir 1 , and this value was $Q \operatorname{so}_{1}(j)$;

4. The yield $Q y_{1}$ was incrementally increased and $Q s o_{1}(j)$ was computed at each new $Q y_{1}$ until the reservoir's usable storage was completely depleted for no more than one month of the synthetic record. The yield at which this criterion was met was defined as reservoir 1's uncorrected firm yield;

5. The correction factor that accounts for the model time step was applied to the final value of $Q y_{1}$, which resulted in the corrected firm-yield value for reservoir 1 ;

6. The value of the uncontrolled release $Q s o_{l}(j)$ that resulted from the operation of reservoir 1 at the firm yield was included as an inflow in the water-balance equation for reservoir 2 (fig. $12 A$ ); and

7. Steps 1 through 5 were repeated for the same period of the historical record for reservoir 2 .

The water being released from one reservoir to another was assumed to be transported through an open channel of adequate volume to transport all of the water from reservoir 1 to reservoir 2 (MassDEP, 1996). Field inspection of the reservoirs in this study confirmed this to be the case for reservoir systems connected by gravity; however, if a pipe or control structure had connected the reservoirs, flow would have been constrained and the connection would have been treated as though it were a pumped system.

Water-use data are reported only for water sent to the treatment plant at the terminal reservoir in the system. No direct guidance is provided in the MassDEP guidance document (MassDEP, 1996) as to how to account for seasonal variations in demand from reservoirs with no direct withdrawals; therefore, the same peak-usage factors computed for the terminal reservoir were applied to other reservoirs in the system. Thus, the amount of stress applied to the terminal reservoir was assumed to be transferred to the other reservoirs in the system. Note that in figure $12 A$, the peak-usage factors in the water-balance equation for reservoir 1 are the same peakusage factors in the water-balance equation for reservoir 2 .

\section{Reservoirs Connected by Pumping}

The procedure used to estimate the firm yield for a reservoir that receives water by pumping is similar to that used to estimate the firm yield for a reservoir that receives water by gravity; however, monthly usage $\alpha_{1}(j) n(j) Q y_{1}$ from reservoir 1 is used in the water-balance equation for reservoir 2 (fig. 12B). The uncontrolled releases from reservoir $1 Q s o_{l}(j)$ are still calculated but do not contribute to the water-balance equation for reservoir 2. Additionally, because the water in reservoir 1 is pumped to reservoir 2 , water-use data are typically available for both reservoirs, and peak-usage factors $\alpha_{l}(j)$ and $\alpha_{2}(j)$ can be computed independently. To estimate the firm yields of reservoirs 1 and 2 successively, when the reservoirs are connected by pumping, the following steps were used:

1. Known inflow and outflow values for the water-balance equation for reservoir 1 were assembled from the historical record;

2. The water-balance equation for reservoir 1 was solved with the yield $Q y_{1}$ initially set to 0 (fig. 12B);

3. The yield $Q y_{1}$ was incrementally increased and $\alpha_{1}(j) n(j) Q y_{1}$ was computed at each new $Q y_{1}$ until the reservoir's usable storage was completely depleted for no more than one month of the synthetic record. The yield at which this criterion was met was defined as reservoir 1's uncorrected firm yield;

4. The correction factor that accounts for the model time step was applied to the final value of $Q y_{1}$, which resulted in the corrected firm-yield value for reservoir 1 ;

5. The value of the monthly usage $\left.\alpha_{1}(j)\right)(j) Q y_{1}$ that resulted from the operation of reservoir 1 at the firm yield was included as an inflow in the water-balance equation for reservoir 2 (fig. 12B); and

6. Steps 1 through 4 were repeated for the same period of the historical record for reservoir 2 . 
Table 9. Firm-yield estimates determined by the historical record of streamflow and precipitation for 31 reservoirs belonging to one of 11 multiple-reservoir systems in Massachusetts. Reservoir connections are shown in the appendix (on CD-ROM). Total reservoirsystem yield includes the additional yield that can be withdrawn from the other reservoirs in the reservoir system although one reservoir has depleted all available storage.

[Reservoir ID: identifier from figure 3. DPW, Department of Public Works; Mgal/d, million gallons per day]

\begin{tabular}{|c|c|c|c|}
\hline Water supplier & Reservoirs in the system & Reservoir ID & Firm yield, in Mgal/d \\
\hline \multirow[t]{4}{*}{ Danvers Water Department } & Emerson Brook (Forest Street Pond) & 44 & 0.37 \\
\hline & Swan Pond & 45 & 0.42 \\
\hline & Middleton Pond & 46 & 1.42 \\
\hline & Total Reservoir-System Yield & & 2.30 \\
\hline \multirow[t]{4}{*}{ Fitchburg Water Department } & Bickford Reservoir & 25 & 2.12 \\
\hline & Mare Meadow Reservoir & 26 & 4.73 \\
\hline & Meetinghouse Reservoir & 27 & 6.18 \\
\hline & Total Reservoir-System Yield & & 19.50 \\
\hline \multirow[t]{4}{*}{ Fitchburg Water Department } & Scott Reservoir & 29 & 0.39 \\
\hline & Fitchburg Reservoir & 31 & 1.34 \\
\hline & Lovell Reservoir & 30 & 1.55 \\
\hline & Total Reservoir-System Yield & & 6.24 \\
\hline \multirow[t]{4}{*}{ Leominster DPW-Water Division } & Haynes Reservoir & 37 & 0.18 \\
\hline & Morse Reservoir & 35 & 0.24 \\
\hline & Distributing Reservoir & 34 & 0.13 \\
\hline & Total Reservoir-System Yield & & 0.85 \\
\hline \multirow[t]{4}{*}{ Leominster DPW-Water Division } & Notown Reservoir & 38 & 2.05 \\
\hline & Goodfellow Pond & 32 & 0.19 \\
\hline & Simonds Pond & 33 & 0.34 \\
\hline & Total Reservoir-System Yield & & 2.76 \\
\hline \multirow{3}{*}{$\begin{array}{l}\text { Marlborough DPW-Water and Sewer Divi- } \\
\text { sion }\end{array}$} & Williams Lake & 40 & ${ }^{1} 0$ \\
\hline & Millham Reservoir & 39 & 1.39 \\
\hline & Total Reservoir-System Yield & & 1.39 \\
\hline \multirow[t]{3}{*}{ North Brookfield Water Department } & Horse Pond & 23 & 0.47 \\
\hline & Doane Pond & 22 & 0.20 \\
\hline & Total Reservoir-System Yield & & 1.23 \\
\hline \multirow[t]{3}{*}{ Pittsfield Water Department } & Sandwash Reservoir & 3 & 1.12 \\
\hline & Farnham Reservoir & 8 & 2.86 \\
\hline & Total Reservoir-System Yield & & 4.69 \\
\hline \multirow[t]{6}{*}{ Southbridge Water Department } & Hatchet Pond & 20 & 0.44 \\
\hline & Hatchet Brook Reservoir \#5 & 17 & 0.90 \\
\hline & Cohasse Brook Reservoir & 21 & 1.41 \\
\hline & Hatchet Brook Reservoir \#4 & 18 & 2.12 \\
\hline & Hatchet Brook Reservoir \#3 & 19 & 0.60 \\
\hline & Total Reservoir-System Yield & & 6.48 \\
\hline \multirow[t]{3}{*}{ South Deerfield Water Supply District } & Roaring Brook Reservoir & 12 & 1.22 \\
\hline & Whately Reservoir & 13 & 0.10 \\
\hline & Total Reservoir-System Yield & & 1.45 \\
\hline \multirow[t]{4}{*}{ Winchester Water Department } & North Reservoir & 43 & 0.44 \\
\hline & Middle Reservoir & 42 & 0.63 \\
\hline & South Reservoir & 41 & 0.40 \\
\hline & Total Reservoir-System Yield & & 3.36 \\
\hline
\end{tabular}

${ }^{1}$ Reservoir has no intake structure to withdraw water. 
This analysis is based on the assumption that the pump capacity was equal to or greater than the yield from the reservoir $1\left(\alpha l(j) n(j) Q y_{1}\right)$. The maximum capacity of the pump was determined from public water-supply records and compared with the total monthly usage to ensure that the amount of water being transported did not exceed the pump's capacity. If the usage exceeded the pump's capacity in a given month, then the excess water was included in the usable storage of reservoir 1.

Although not considered in the simulation of reservoirs connected by pumping, factors such as pipe-wall friction will limit the capacity of the pump to transport water and may decrease the amount of water that can be transported from one reservoir to another.

\section{Estimation of the Firm Yield of a Reservoir System}

The system firm yield of any combination of reservoirs and connections can be determined by breaking the system into smaller subsystems to which the procedures outlined in the preceding sections can be applied. The firm yield of a reservoir system is then determined by adding the firm yields for the reservoirs in the system and applying a simple approximation described in MassDEP (1996) guidance document to account for reservoir-operating rules. Although each reservoir in the system has depleted all available storage in, at most, one month of the historical record, not all of the reservoirs in the system may have depleted all available storage during the same month. Thus, even if one reservoir's usable storage becomes fully depleted, the other reservoirs in the system may still have available storage, which, when divided by the number of days in the month, can be converted to a yield. By converting this remaining water to a yield, the amount is then added to the sum of the individual reservoirs' firm yields to obtain the total firm yield for the reservoir system. Previous firm-yield estimates that were available compared well with the estimates from this study. Firm yields for the multiplereservoir systems are shown in table 9, and diagrams of the 11 systems are provided in the appendix (on CD-ROM).

For one system of reservoirs within the Fitchburg drinking-water supply system (the system consisting of Bickford, Mare Meadow, and Meetinghouse Reservoirs), the system firm yield was almost three times as high as the reported usage. The three reservoirs in this system were among the largest reservoirs in the study, and their combined capacity was almost three times greater than the second-largest reservoir system in the study (Fitchburg, Lovell, and Scott Reservoirs) (table 3 and appendix).

\section{Summary and Conclusions}

Procedures developed by the Massachusetts Department of Environmental Protection (MassDEP) to estimate the firm yield of a reservoir or system of reservoirs were assessed on the basis of data from 46 reservoirs in Massachusetts. This study evaluated the factors that affect the estimation of firm yield and applied the firm-yield estimation procedures to the study reservoirs and reservoir systems. These factors included the method that estimates streamflow at an ungaged location and the bootstrap technique, which constructs a synthetic record of precipitation and streamflow.

The estimation of firm yield for a reservoir or system of reservoirs requires the selection of an appropriate meteorological station (to estimate precipitation to and evaporation from the reservoir) and streamflow station (to estimate streamflow into the reservoir). The meteorological station should be the closest available to the reservoir's contributing area and have a period of record that includes the 1960s drought-of-record in Massachusetts. The reference streamflow-gaging station should be in or as close as possible to the reservoir's contributing area and also have a period of record that includes the 1960s drought. In addition, the streamflow should be minimally altered by surface-water regulation or by reduction of base flow due to ground-water pumping. An appendix to this report on CD-ROM provides a list of 26 streamflow stations across Massachusetts that fit these criteria.

Streamflow to the reservoir is estimated by the QPPQ method. To estimate flows at an ungaged location, the QPPQ method uses six properties of the reservoir's drainage basinprecipitation, snowfall, maximum soil retention, drainage area, basin slope, and basin elevation - and the exceedence probabilities for the index station. Streamflow estimates determined by the QPPQ method were most sensitive to (in decreasing order) precipitation, drainage area, and maximum soil retention. To test the overall accuracy of the QPPQ method in estimating streamflow, the method was used to predict flows at two USGS streamflow-monitoring stations with long-term records. The simulated flows agreed well with the measured observations, except at extreme high and low flows. For nine of the reservoirs, application of the QPPQ method resulted in simulated negative flows. A correction was applied to the QPPQ method to prevent the simulation of negative flows and this correction did not change flow values substantially.

The MassDEP Firm Yield Estimator guidance document recommends the use of a 1,000-year synthetic record constructed by sampling 2-year blocks of concurrent streamflow and precipitation records 500 times; however, the synthetic record has the potential to generate records of precipitation 
and streamflow that do not reflect the worst historical drought in Massachusetts. For reservoirs whose periods of drawdown are not greater than the block length, the bootstrap does not offer any more information about the firm yield of a reservoir than the historical record does. For some reservoirs, the use of a synthetic record to determine firm yield resulted in as much as a 30-percent difference between firm-yield values from one simulation to the next; yet, for other reservoirs, the use of a synthetic record did not result in any difference in firm yield as compared to the firm yield determined by the historical record. Furthermore, the assumption that the synthetic traces of streamflow are statistically equivalent to the historical record is not valid.

None of the reservoirs or reservoir systems examined in this study had required releases or withdrawals by other users; in some cases, however, it was found that these additional demands could result in a firm yield equal to zero. This is because the required releases or withdrawals already result in the complete depletion of reservoir storage without allocating water for public supply.

The estimation of the firm yield for a system of reservoirs is highly dependent on the system's configuration. Consideration must be given to how the reservoirs transport water within the system (by gravity or pumping), factors affecting the efficiency of water transport from one reservoir to another, and the application of seasonal peak-usage factors.

Firm yields for 25 reservoir systems were determined on the basis of analysis of the historical record of streamflow and precipitation. Current water-use data indicate that, on average, 20 of the 25 reservoir systems in the study were operating below their estimated firm yield; during months with peak demands, withdrawals exceeded the firm yield for 8 reservoir systems.

\section{Acknowledgments}

The authors thank Paul Blain, Thomas Lamonte, and Stephen Hallem of the Massachusetts Department of Environmental Protection, Richard Vogel of Tufts University, Phillip Zarriello of the USGS, and Neil Fennessey of the University of Massachusetts-Dartmouth for their technical reviews of this report. The authors also thank Robert Breault of the USGS for his help in collecting the bathymetric data, Jason Sorenson of the USGS for his help with the sensitivity analysis for the QPPQ method, and Gene Parker and Lance Ostiguy of the USGS for their help in calculating the SOIL values.

\section{References Cited}

Armstrong, D.A., Parker, G.W., and Richards, T.A., 2004, Evaluation of streamflow requirements for habitat protection by comparison to streamflow characteristics at index streamflow-gaging stations in southern New England: U.S. Geological Survey Water-Resources Investigations Report 03-4332, 99 p.

Environmental Systems Research Institute, Inc. (ESRI), 1994, ARC/INFO user guides, version 7: Redlands, CA, Environmental Systems Research Institute, Inc., 626 p.

Fennessey, N.M., 1994, A hydro-climatological model of daily streamflow for the northeast United States: Medford, MA, Tufts University, Ph.D. dissertation, variously paged.

Fennessey, N.M., 1995, The sensitivity of reservoir-yield estimates to model time step surface-moisture fluxes: Journal of Water Resources Planning and Management, v. 121, no. 4, July/August 1995, p. 310-317.

Fennessey, N.M., and R. M. Vogel, 1996, Regional models of potential evaporation and reference evapotranspiration for the northeast USA: Journal of Hydrology, v. 184, p. 337-354.

Hirsch, R.M., 1982, A comparison of four streamflow record extension techniques: Water Resources Research, v. 18, no. 4, p. 1081-1088.

Hutchinson, M.F., 1989, A new procedure for gridding elevation and stream line data with automatic removal of spurious pits, Journal of Hydrology, v. 106, p. 211-232.

Massachusetts Department of Environmental Protection (MassDEP), 1996, Estimating the firm yield of a surface water reservoir supply system in Massachusetts-A guidance document, version 1.0: Prepared by N. Fennessey for the Massachusetts Department of Environmental Protection, Office of Watershed Management, variously paged.

Massachusetts Department of Environmental Protection (MassDEP), 2000, Firm yield estimator, version 1.0, Software Documentation: Prepared by Cambridge Environmental Inc. for the Massachusetts Department of Environmental Protection, Office of Watershed Management, variously paged. 
Natural Resources Conservation Service, 1986, Urban hydrology for small watersheds: Natural Resources Conservation Service, Conservation Engineering Division, Technical Release 55, 164 p. (http://www.hydrocad.net/tr-55.htm).

New England Water Works Association, 1969, Progress report of the committee on rainfall and yield of drainage areas: Journal of the New England Water Works Association, v. 83 , no. 2 , p. $166-189$.

Office of Geographic and Environmental Information (MassGIS), 2005a, Commonwealth of Massachusetts Executive Office of Environmental Affairs, Land-use data layers for Massachusetts; accessed on July 11, 2005, at http://www. mass.gov/mgis/ftplus.htm.

Office of Geographic and Environmental Information (MassGIS), 2005b, Commonwealth of Massachusetts Executive Office of Environmental Affairs, 1:5,000-scale black and white orthophotos for Massachusetts; accessed on July 11, 2005, at http://www.mass.gov/mgis/dwn-imgs.htm.

Ries, K.G., III, Friesz, P. J., Freeman, Aleda, and Singh, Raj, 2000, Obtaining streamflow statistics for Massachusetts streams on the World Wide Web: U.S. Geological Survey, Fact Sheet 104-00, 4 p.

Slack, J.R., and Landwehr, J.M., 1993, Hydro-Climatic Data Network (HCDN): A U.S. Geological Survey streamflow data set for the United States for the study of climate variations, 1874-1988: U.S. Geological Survey Open-File Report 91-129, 193 p.

Vogel, R.M., and Shallcross, A.M., 1996, The moving blocks bootstrap versus parametric time series: Water Resources Research, v. 32, p. 1875-1882. 


\section{Appendix. Data, Records, and Input Files for Use in Estimating the Firm Yield of Massachusetts Drinking-Water-Supply Reservoirs}

\section{Description of Appendix}

The appendix is on a CD-ROM. The purpose of this CD-ROM is to present all data used to estimate the firm yield of selected reservoir systems in Massachusetts, allow the user to compute evaporation and streamflow records for each of the study reservoirs, and provide streamflow records of relatively unaltered USGS stream-gaging stations across New England to be used with the Massachusetts Firm Yield Estimator, version 1.0 (MAFYE) software (MassDEP, 2000).

The software requirements to access the files on the CD-ROM are Adobe Acrobat Reader, Microsoft Access (2000 file format or higher), and a text editor. The user does not need any previous experience working with a Microsoft Access database. All files on the CD-ROM are contained in the master folder titled Appendix. Within the master folder, there are five folders and one relational database that organize the data on the CD-ROM. The names and contents of the folders are explained in the README folder on the CD-ROM.

All files on the CD-ROM can be viewed by double-clicking on the file. Most files can also be viewed by navigating the relational database. A description of how to work with the files on the CD-ROM and navigate the database is provided in the documents in the README folder on the CD-ROM. The relational database and supporting files on the CD-ROM present the compiled data for each study reservoir; allow the user to compute, view and export evaporation and streamflow records for each study reservoir; present public-water-supplier contact information; and give the connectivity of the reservoirs and the estimated firm yields of the reservoirs or reservoir systems for a given public water supplier. 
For additional information write to:

Director,

USGS Massachusetts-Rhode Island Water Science Center

10 Bearfoot Road

Northborough, MA 01532

or visit our Web site at http://ma.water.usgs.gov 